\title{
NEUROPHARMACOLOGICAL EFFECTS OF NIGERIAN HONEY IN MICE
}

\author{
Moses Atanda Akanmu*, Temitope Adunni Olowookere, Soliu Abiola Atunwa, Basirat \\ Olufunmilola Ibrahim, Oluwafunmilayo Fatima Lamidi, Philomena Arekekhuegbe Adams, Bolanle \\ Olubunmi Ajimuda, Lilian Edelauvo Adeyemo
}

\author{
Department of Pharmacology, Faculty of Pharmacy, Obafemi Awolowo University, Ile - Ife, Nigeria \\ *Email: maoakanmu@yahoo.com or makanmu@,oauife.edu.ng
}

\begin{abstract}
Honey is a natural sweet substance that bees produce by transforming flower nectar or other sweet secretions of plants. It has widespread use in traditional medicine in various parts of the world. It has been reported to assist in building the entire central nervous system. The beneficial effects of honey have been attributed to the possible polyphenolic contents and some other constituents. The geographical locations and the sources of plant nectars may contribute to the effects of honey samples. Thus, we evaluated the neuropharmacological effects of six samples of honey $(10 \%, 20 \%$ and $40 \% \mathrm{v} / \mathrm{v}$, p.o.) from three geographical locations of Nigeria using the following behavioral models: Novelty-induced behaviors (NIB), learning and memory, pentobarbital-induced hypnosis, anxiolytic, anticonvulsant, analgesic and antidepressant models in mice. The results showed that honey significantly $(\mathrm{p}<0.05)$ decreased locomotion and rearing behaviors in NIB and amphetamine-induced locomotor activity when compared to the control group. Exploratory behavior was significantly increased in both holeboard and elevated plus maze but had no significant effect on spatial working memory. Honey sample from Umudike has significant hypnotic and anticonvulsant effects. The antinociceptive models (hot plate and tail flick tests) showed that the honey samples significantly increased the pain reaction time and naloxone blocked these central antinociceptive effects. The force swimming test showed that only the Idanre (ID) honey sample had antidepressant effect. In conclusion, some of these honey samples have central inhibitory property, anxiolytic, antinociceptive, anticonvulsant and antidepressant effects, thus may be used as nutraceutic. It can also be inferred that some of these effects are probably mediated through dopaminergic and opioidergic systems.
\end{abstract}

Key words: Honey, neuropharmacology, traditional medicine, anxiolytic, antinociceptive, antidepressant, mice

\section{Introduction}

Honey is a natural product of bees, Apis mellifera adansonii (Hymenoptera: Apidae), that has been used as a natural sweetener and a healing agent since antiquity (Adebiyi et al., 2004; Crosby et al., 2004). It is produced by transforming flower nectar or other sweet secretions of plants by bees. Juszczak et al. (2009) reported that it is an easily assimilable food with valuable nutritive product for children, athletes and convalescents and health promoting properties. Honey is a good source of monosaccharides, macro- and micro-nutrients, antioxidants, group of B vitamins, enzymes and inhibines (Frankel et al., 1998; Gheldof and Engeseth, 2002; Taormina et al., 2001; Molan, 1996). It has been reported to help invigorate the entire central nervous system (CNS). Honey has been used in ethno-medicine since the early humans, and in more recent times. Its role in the treatment of burns, gastrointestinal disorders, asthma, infected wounds and skin ulcers has been "rediscovered" [Al-Mamary et al., 2002]. It therefore has wide uses in traditional folk medicine and apitherapy. The medicinal quality, taste of honey differs according to the geographical area and the species of plants from which it has been collected. Reports showed that the consumption of honey actually results in weight loss as compared with diets of sugar or Hydro Fluorocarbons. It is also reported to improve night's sleep, facilitate restorative sleep when taken before bedtime by contributing to the release of melatonin in the brain and it helps to enhance immunity and facilitate the rebuilding of tissues during rest (Fessenden, 2008). The nutraceutical effects observed in honey have been traced to the presence of some antioxidant substances and flavonoids. Unprocessed honey has been reported to keep free radicals at bay and reduce the damage done to the colon in colitis (Bilsel et al., 2002). It is has also been found that honey can boost immunity by increasing neutrophil count, decreasing thrombocytopenia and stabilizing hemoglobin levels at $>11 \mathrm{gm} / \mathrm{dl}$ and more effective as cough suppressant for children 2-18 years than dextromethorphan and effective in the treatment of conjunctivitis in rats (Al-Waili, 2004, Paul et al., 2007).

Traditionally in Nigeria honey has been used in the following forms to treat various types of ailments such as: Bronchial cough (mixture of equal parts of honey and fresh lemon juice); Feverish cough ( mixture of 1 fluid ounce each of honey, olive oil, lemon juice and take several times a day); Colds (mixture of honey with cidar apple vinegar); Sore or irritated throats (honey drinks- mixture of a gargle of 1 quart water, $125 \mathrm{~g}$ honey and $5 \mathrm{~g}$ alum);Ulcers in the mouth (mixture of 2 tablespoons of honey, 2 tablespoons glycerin, 1 tablespoon lemon juice and a dash of ginger);Tension (regular intake of honey to relax the nerves); Burns and wounds and Earache (put drops of honey on a piece of cotton wool and put it into the ear). The beneficial effects of honey have been attributed to the possible polyphenolic contents and some other constituents. The composition of honey is variable, owing to the differences in plant types, climate, environmental conditions, and contribution of the beekeeper [Anklam, 1998]. Its 
composition has also been shown to depend largely on its floral source. Honey has been reported to contain about 200 substances and is considered as an important part of traditional medicine [White, 1979]. The average honey is 79.6\% sugar and $17.2 \%$ water. Honey contains more than 25 different sugars, each one having a different function in the human metabolism. Many of these sugars do not occur in nectar but are formed by the bees during ripening. The primary sugars are fructose (38.2\%) and glucose (31.3\%). These are 'simple', 6-carbon sugars that are readily absorbed by the body. Other sugars include maltose (7.3\%), a $12-$ carbon sugar composed of 2 glucose molecules, and sucrose (1.3\%), a 12-carbon sugar composed of glucose and a fructose molecule. Honey also contains acids $(5.7 \%)$, some protein $(2.6 \%)$, a small amount of minerals $(1.7 \%)$ and a number of other minor components including pigments, flavor and aroma substances, sugar alcohols, colloids and vitamins, pollen, enzymes, minerals, vitamins and amino acids. This latter group of materials constitutes about $2.2 \%$ of the total composition. Geographical locations and the plants in the environment where the honey is harvested may have significant influence on its composition and effectiveness. Previous studies by Gross and co-workers have shown that daily consumption of honey raises blood levels of protective antioxidant compounds in humans. They found that there was a direct link between the subjects honey consumption and the level of polyphenolic antioxidants in their blood (Gross et al., 2004).

Therefore, since honey is a common basic constituent of a large number of traditional medicines in Nigeria and there is a great awareness on the importance of honey in improving health and there is no scientific information on the neuropharmacological effects of Nigerian honey, we therefore, investigated the general pharmacological (Novelty-induced behaviors, learning and memory, hypnotic, anxiolytic, anticonvulsant and analgesic) effects in mice of six samples of honey from three geographical locations of Nigeria.

\section{Materials and Methods \\ Honey Samples origin:}

Six major floral honeys were obtained from different regions of Nigeria as shown in Plate 1 (Idanre (ID), Ile-Ife (IF) [Western); Ewu (EW) (Mid-western); Umudike (UD) (Eastern); Kaduna (KD) and Jigawa (JG) (Northern) regions. The type and place of origin, as well as the family, scientific, common names of the plants that form the basic flora of the honey samples are as shown in Table 1.

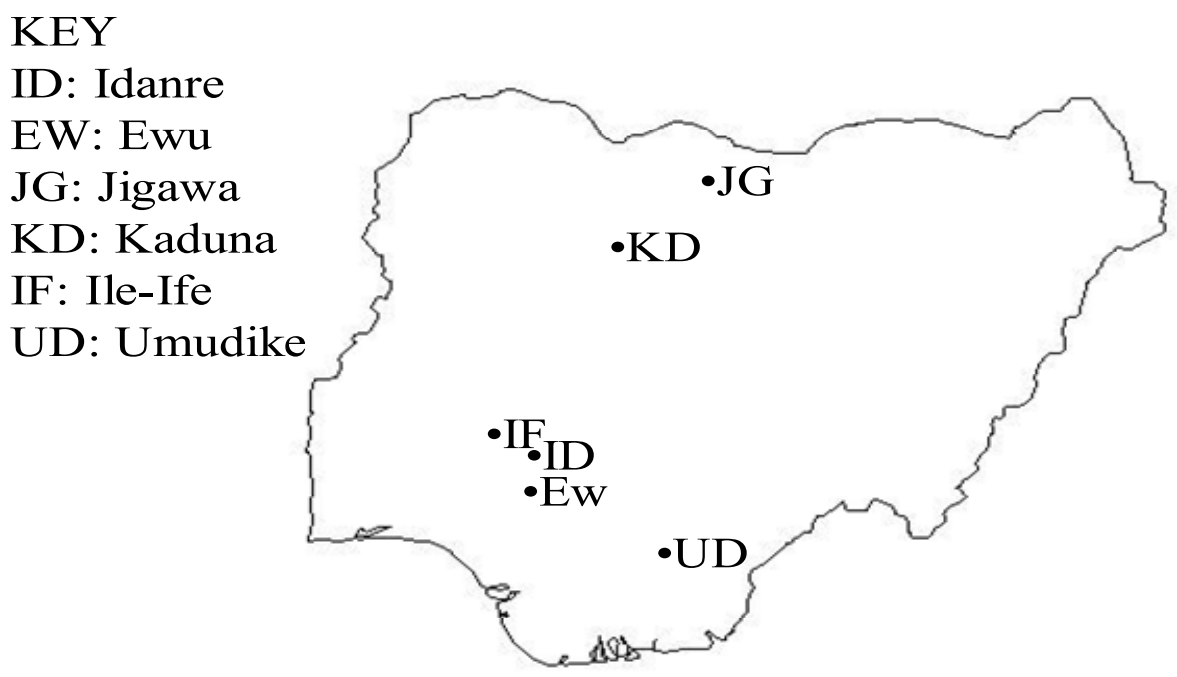

Plate 1. Location of honey samples origin on Nigeria map 

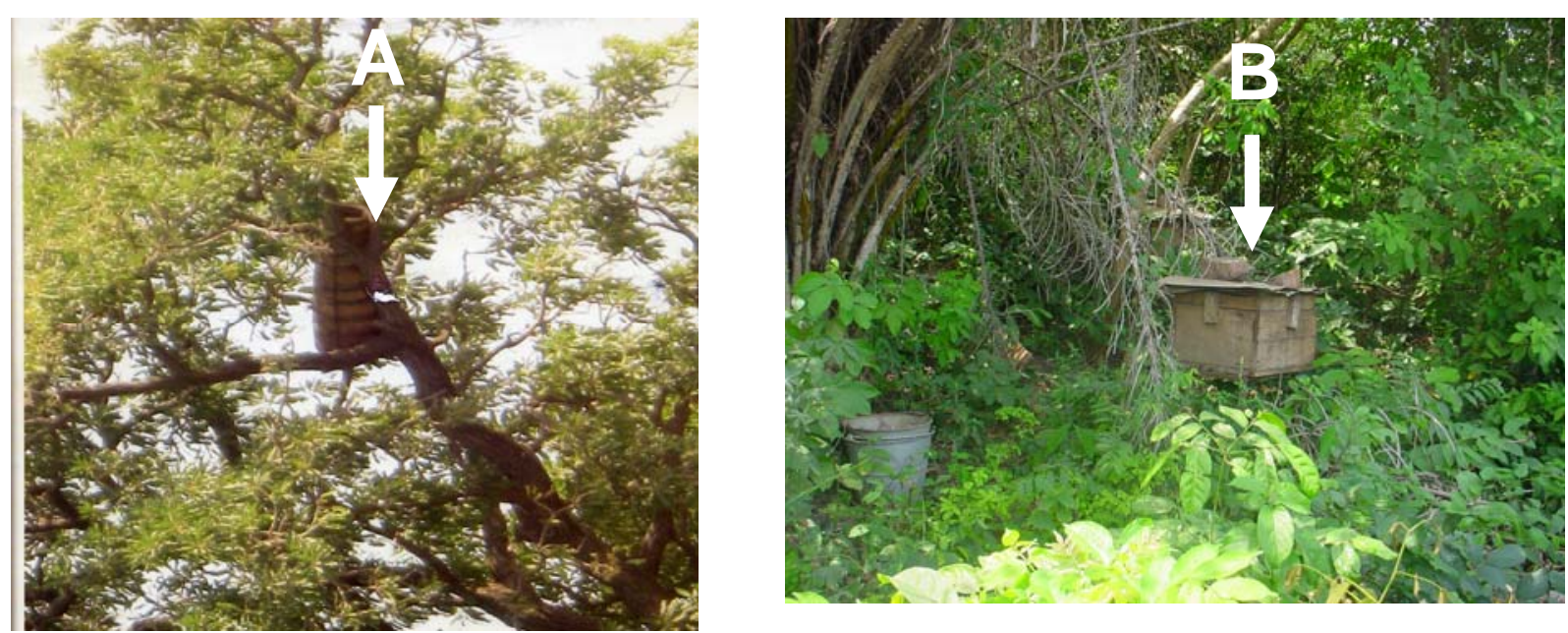

Plate 2a and b. Examples of Beehives in Nigeria (A: Jigawa -Common in the Northern region; B: Ewu-Common in the Western, Mid-western and Eastern regions)

Table 1: Characterization of the multiflora honey samples:

$\begin{array}{cllll}\text { Place } & \text { Honey sample } & \text { Family } & \text { Scientific name } & \text { Common name } \\ \text { Idanre } & \text { Dark brown } & \text { Sterculaceae } & \text { Theobroma cacao } & \text { Cocoa } \\ & & \text { Musaceae } & \text { Musa acuminata } & \text { Banana } \\ & & \text { Sterculaceae } & \text { Cola acuminata } & \text { Kola } \\ \text { Ewu } & \text { Dark brown } & \text { Asteraceae } & \text { Chromolaena odorata } & \text { Siam weed } \\ & \text { Anacardiaceae } & \text { Mangifera indica } & \text { Mango } \\ & \text { Arecaceae } & \text { Elaeis guineensis } & \text { Palm tree } \\ & \text { Rubiaceae } & \text { Morinda lucida } & \text { Morinda } \\ & \text { Lamiaceae } & \text { Tectona grandis } & \text { Common Teak } \\ \text { Jigawa Light brown } & \text { Sapotaceae } & \text { Butyrospermum parkii } & \text { Sheabutter tree } \\ & \text { Mimosaceae } & \text { Parkia biglobosa } & \text { Locustbean tree } \\ \text { Kaduna Light brown } & \text { Sapotaceae } & \text { Butyrospermum parkii } & \text { Sheabutter tree } \\ & \text { Mimosaceae } & \text { Parkia biglobosa } & \text { Locustbean tree } \\ & \text { Poaceae } & \text { Pennisetum glaucum } & \text { Pearl millet } \\ & \text { Poaceae } & \text { Sorghum bicolor } & \text { Sorghum } \\ \text { Ife } & \text { Euphorbiaceae } & \text { Manihot esculenta } & \text { Cassava } \\ & \text { Light brown } & \text { Musaceae } & \text { Musa acuminata } & \text { Banana } \\ & \text { Anacardiaceae } & \text { Mangifera indica } & \text { Mango } \\ & \text { Anacardiaceae } & \text { Anacardium occidentale } & \text { Cashew } \\ \text { Umudike Light brown } & \text { Arecaceae } & \text { Elaeis guineensis } & \text { Palm tree }\end{array}$

Honey Preparation for behavioral studies (mice)

Each honey sample was prepared using normal saline as the vehicle to obtain the three dose levels of 10,20 or $40 \% \mathrm{v} / \mathrm{v}$. The freshly prepared honey was always administered to different groups of mice orally at a maximum volume of $10 \mu \mathrm{l} / \mathrm{g}$ body weight and normal saline was administered to the control group.

\section{Animals}

The animals used for the experiments were albino mice of both sexes $(22.0 \pm 0.1 \mathrm{~g})$,) that were purchased from the NAFDAC, Institute of Medical Research Yaba, Lagos, Nigeria. Animals were housed in plastic cages with stainless steel wire coverings. The cages were kept clean at all times and food and water were provided ad libitum. The mice were housed in the animal house of Pharmacology Department, Faculty of Pharmacy, Obafemi Awolowo University, Ile-Ife. All rules applying to animal care and safety were observed. They were assigned to different groups of five-member each and used in the experiments. Generally, animals were handled for 5 min daily, 2 weeks before the experiment to habituate them to handling, presence of investigator and experimental environment. The animals were allowed to acclimatize to the testing area for 15-30 min before administration of 
samples or normal saline (vehicle). The entire behavioral experimental period was between 8:00 $\mathrm{h}$ and 16:00 daily. The experimental protocols followed the international accepted principles for Laboratory Animal Use and Care (EEC Directive of 1986; 86/609/EEC) (Waldegrave, 1986).

Drugs

Pentobarbital, amphetamine, scopolamine, naloxone, picrotoxin, (Sigma, St. Louis, MO, USA) and diazepam (Roche, Lagos, Nigeria).

Open field model

Novelty- Induced Behavior (Locomotion, Rearing and Grooming)

One hundred and seven mice of both sexes were divided into nineteen groups ( $\mathrm{n}=5-8$ per group) based on each honey sample at three dose levels and vehicle (normal saline).Twenty minutes $(20 \mathrm{~min})$ period of each of the following behavioral states: locomotion, rearing and grooming was observed and scored at ten minutes time interval. This was to characterize the behavioral changes induced by the honey sample in the mice when placed in an open field arena. Briefly, the structure consist of a rectangular arena composed of a hardboard floor $(60 \times 60 \mathrm{~cm})$ with a surrounding wall $64 \mathrm{~cm}$ height, both made with white painted wood. The floor was divided by permanent red marker into squares of $9 \mathrm{~cm}$ at the bottom (on the external surface). Generally, spontaneous motor activity was monitored for $20 \mathrm{~min}$ in the modified open field method as described by Gomes et al. (2008). Briefly, after the administration of test substances each mouse was introduced into the cage and the total locomotion (number of floor units entered the floor of square crossed with all paws), frequency of grooming (the number of body cleaning with paws picking of the body and pubis with mouth and face washing actions) and rearing frequency (number of times the animal stood on its hind legs or with its forearm against the wall of the observation cage or in the free air) within 10 min interval were counted. Before introducing each animal, the arena was cleaned with $5 \%$ alcohol to eliminate the possible bias due to the odor that could be left by the previous animals.

\section{Effects of honey on amphetamine-induced NIB}

This behavioral model was used in the study of the mechanism of action of honey on novelty-induced behavior (Chen et al., 2007). Generally, spontaneous motor activity was monitored for 20 minutes in the modified open field method as described in the earlier NIB above. Seventy eight mice were used in this study and they were divided into thirteen groups of four honey samples at three dose levels, vehicle and standard drug. Honey was administered at different doses $1 \mathrm{~h}$ prior to administration of amphetamine $(2 \mathrm{mg} / \mathrm{kg}$, i.p.) and immediately after the injection of amphetamine each mouse was introduced into a cage and total locomotion ( number of floor units entered - the floor of the squares crossed with all paws), frequency of grooming (the number of body cleaning with paws, picking of the body and pubis with mouth and face-washing actions) and rearing frequency (number of times, the animal stood on its hind legs or with its fore arms against the wall of the observation cage or in the free air) within 10 minutes interval were counted for the total $20 \mathrm{~min}$.

\section{Pentobarbital-induced hypnosis}

This experiment was carried out to determine the effects of honey on latency and prolongation of total sleeping time induced by pentobarbital. Pentobarbital $(40 \mathrm{mg} / \mathrm{kg})$ was administered intraperitoneally in an individual sequence in mice $(\mathrm{n}=110)$ with the volume $(10 \mu \mathrm{l} / \mathrm{g}$ of animal body weight) one hour after the administration of different doses of honey orally and each mouse was placed in an observation box (a rectangular open box composed of hardboard floor $\left(36 \mathrm{x} 36 \mathrm{~cm}^{2}\right)$ with a surrounding wall $30 \mathrm{~cm}$ height. The sleep latency and total sleeping time were noted and recorded for each mouse. The sleep latency is defined as the period between the time of pentobarbital administration and observation of loss of righting reflex while the total sleeping time is the period from loss of righting reflex (loss of consciousness) and waking up (recovery of consciousness)(Gomes et al., 2008). The control group animals were administered normal saline (negative control) and diazepam (2 mg/kg, i.p.) was administered to another group (positive control).

\section{Nootropic effects}

For the evaluation of nootropic effect, groups of albino mice were subjected to Y-maze and elevated plus-maze models 1 hour after treatment with honey (alone) or with prior administration of scopolamine.

\section{Y-Maze Model (Spatial working memory)}

It is well known that spontaneous alternation is a measure of spatial working memory. The Y-maze has been reported ton be used as a measure of short term memory, general locomotor activity and stereotypic behavior [Heo et al., 2003; Mamiya et al., 2004; Sarter et al., 1988]. The Y-maze is composed of three equally spaced arms (120; $41 \mathrm{~cm}$ long x $15 \mathrm{~cm}$ high). The floor of each arm consists of wood $5 \mathrm{~cm}$ wide. Each group of animals was tested 1 hour after administration of vehicle and different doses of honey solution $(10,20,40 \% \mathrm{~V} / \mathrm{v})$-one hundred and seventeen mice $(\mathrm{n}=117)$ were used in this section. In the second phase where 
scopolamine was used to induce memory impairment in another set of animals-one hundred and fifty-two mice ( $\mathrm{n}=152$ ) were pretreated respectively with the concentration of honey samples required $(10,20$ or $40 \% \mathrm{v} / \mathrm{v})$ and were left for 45 minutes after which scopolamine was administered at the dose of $3 \mathrm{mg} / \mathrm{kg}$ intraperitoneally. The mice were kept for another 15 minutes after which spontaneous alternation test [Y-Maze] was observed for 6 minutes. Generally in Y-maze, each mouse was placed in one arm of the compartments and was allowed to move freely for 6 minutes and the examined parameters were total arm entries and spontaneous alternation. The spontaneous alternation percentage (SA\%) was defined as a ratio of the arm choices that differed from the previous two choices (successful choices) to total choices during the run (total entry minus two). An arm entry is when the body of the mouse, except for its tail, completely entered into an arm compartment. The sequence of the arm entries, which are alternations, was mutually recorded. For instance, each alternation is followed by a comma in the following sequence of arm entries (each arm is labeled A, B, or C): ACB, CAB, C, A, CAB, C, A. In this example, the mouse entered 13 arms, eight of which were alternations. The number of maximum spontaneous alternation is therefore the total number of arms entered minus two and the percentage calculated thus:

$\underline{\text { Actual alternations }} \times 100$

Maximum alternations

Therefore, the spontaneous alternation percentage in this case is $61.5 \%$. The model was cleaned with ethanol and permitted to dry between sessions to remove the previous animal's odor as well as and feaces therein. The experiment was performed on all the mice as well as on the control standard using normal saline.

\section{Anxiolytic tests (Hole board and Elevated plus maze) Hole Board}

In the hole board test, a paradigm involving novelty and uncertainty is employed. Head-dipping is generally considered to provide a measure of exploitation that was distinct from motor activity. One hundred and twenty-seven mice $(\mathrm{n}=127)$ were divided into nineteen groups ( $\mathrm{n}=5-9$ per group). The animals were placed on board $(40 \mathrm{X} 40)$ with 16 holes (symmetrically distributed in four rows) 1 -hr after oral administration of vehicle (normal saline) or different doses of honey $(10,20$ and $40 \% \mathrm{v} / \mathrm{v})$. The frequency of head dips into the holes during 6 min was registered immediately after the administration of the honey samples at different doses used and the total locomotion (number of floor units entered-the floor of the squares crossed with all paws) was also recorded. They are expressed as mean total number of head dips [Boissier \& Simon, 1960; Lister, 1987a].

\section{Elevated plus - maze}

The apparatus is made of wood and has two narrow enclosed arms which are bordered by high walls and has two open arms which are essentially unprotected boards; naïve mice will normally prefer to spend much of their allotted time in the enclosed arms. The preference appears to reflect an aversion to the open arms generally by fear and anxiety induced by height and exposure (Rodgers and Cole, 1994). Anxiolytics are known to increase open arms exploration. The elevated plus maze is a modification of the apparatus validated for mice by Lister (Lister, 1987b) consisting of two open arms (30 x $5 \times 0.25 \mathrm{~cm})$ and two closed arms $(30 \times 5 \times 15 \mathrm{~cm})$ emanating from a common central platform $(5 \times 5 \mathrm{~cm})$. The two pairs of identical arms are opposite each other. The entire apparatus is elevated to a height of $50 \mathrm{~cm}$ above floor level. One hundred and fifteen mice were divided into nineteen groups $(n=5-7)$. The animals were administered the three different doses of honey samples and then used in this model. At the start of the session the mouse was placed at the centre of the maze, with its head facing an open arm and allowed to explore the maze for $5 \mathrm{~min}$. During the $6 \mathrm{~min}$ test period, the following measurements were recorded: the number of entries and the time spent in open and closed arms, and the exploratory behavior (total number of arm entries). An entry with all feet put into one arm is defined as an arm entry in this experiment; four groups of mice were tested as described in the experimental procedures above. All the animals were also subjected to this experimental model for anxiety. The elevated plus maze was carefully wiped with a towel wet with methylated spirit after each animal to prevent odor bias. The results were expressed as mean ratio of time spent in open arms to total time spent in both open and closed arms, (percentage of time spent in open arms); mean ratio of entries into open arms to total entries into both open and close arm entries (percentage of number of entries) and number of entries of open arms. The Index open arms avoidance [OIAA] was determined (Trullas and Skolnick, 1993) i.e. IOAA $=100-(\%$ Time spent in open arms $+\%$ entries into open arms $) / 2$; if results is at least 10 point $<$ than vehicle, the sample is anxiolytic, conversely if result is at least 10 points $>$ saline (Vehicle), then the sample is anxiogenic.

\section{Anticonvulsant effect: Pictrotoxin seizure model}

One hundred and sixteen mice $(\mathrm{n}=116)$ were divided into groups for picrotoxin seizure model. Honey was administered orally at doses of 10,20 and $40 \% \mathrm{v} / \mathrm{v} 45 \mathrm{~min}$ prior to the intraperitoneal administration of picrotoxin $(6 \mathrm{mg} / \mathrm{kg})($ Abdul-Guani et al., 1987; Perazzo et al., 2003). Diazepam $(2 \mathrm{mg} / \mathrm{kg})$ as a standard drug was administered intraperitoneally to another group while normal saline was administered to the control group. Each animal was placed in the individual cage for observation period of 30 minutes. The death following the tonic seizures was used as the endpoint. The clonus was characterized by fore limb clonus, Hind limb clonus i.e. localized seizures, before the tonic seizure that involves the whole body, then death. The time taken before the onset of the clonic, tonic seizures and also the duration of the convulsion, and the percentage of seizure and mortality protection were recorded. 


\section{Analgesic effects \\ Hot plate test}

The hot plate test was used to determine the analgesic effect of honey in mice ( $\mathrm{n}=132$ mice). Animals were orally administered honey at different doses $(10,20$ and $40 \% \mathrm{v} / \mathrm{v}$ ) and vehicle (saline) 60 minutes before being placed on the hot plate. Morphine (10 mg/kg, i.p.) was administered to another group of animals as standard drug (positive control).The respective time(s) for paw licking thereafter or jumping on a hot plate at $55^{\circ} \mathrm{C}$ was registered and $30 \mathrm{~s}$ was chosen as cut off time.

\section{Tail immersion test}

The use of immersion of the tail is apparently a variant of the tail flick using radiant heat. However, the most obvious difference is that the area of stimulation is far greater. Immersion of an animal's tail in hot water provokes an abrupt movement of the tail and sometimes the recoiling of the whole body (Romero et al., 2002). The lower two-third of the tail (distal end) was immersed in a beaker containing water kept at $50.0 \pm 0.5^{0} \mathrm{C}$ (Janssen et al., 1963). The time (in seconds) until tail withdrawal from the water was considered the reaction time. The reaction times were recorded at $60 \mathrm{~min}$ each before and after oral administration of honey at different doses, vehicle (control) and morphine $(10 \mathrm{mg} / \mathrm{kg}$, i.p.). One hundred mice $(\mathrm{n}=100)$ were used in this study and thirty five mice $(n=35)$ were used in the second part where the antagonist was used. In another group of mice, administration of the antagonist (Naloxone: $1 \mathrm{mg} / \mathrm{kg}$, s.c.) was made $15 \mathrm{~min}$ before oral administration of $20 \% \mathrm{~V} / \mathrm{v}(10 \mu \mathrm{l} / \mathrm{g})$ of each of the honey samples. Thereafter, the experimental procedure was repeated and reaction times were recorded at 60 min each before and after drug administration respectively. This was used to determine the mechanisms of action of honey samples.

\section{Antidepressant test (Forced swimming test (FST)}

This is a behavioral test used to screen new potent antidepressant drugs in rats and mice (Porsolt et al., 1977a, 1977b and De Vry et al., 1999) with procedure described by Porsolt et al., 1978 used with minor modifications). In the FST, mice are forced to swim in a restricted space from which there is no escape and become immobile. Therefore, FST was carried out in mice $(\mathrm{n}=162)$ individually forced to swim in an open cylindrical container (diameter $12 \mathrm{~cm}$, height $15 \mathrm{~cm}$ ) containing $7 \mathrm{~cm}$ of water at $22.0 \pm 1 .{ }^{\circ} \mathrm{C}$; the duration of immobility or struggling in a period of 6 minutes was scored as described by Eckeli et al. (2000); Cervo et al. (1991). Immobility was judged as when mice ceased to struggle and remained floating in the water, making only necessary movements necessary to keep its head above water. At the end of the session, the animal was removed from water and dried gently. Scoring was done using time sampling technique via two types of active behavior- Immobility and Struggling: swimming and climbing (Detke et al., 1995). Scoring was done every 60 seconds for 6 min using a stop watch kit. Immobility - a mouse was judged to be immobile when it remained floating in the water. Struggling: when mouse made active motions necessary to maintain its head above water. A two min period was allowed for acclimatization and scoring was taken at the last 4 min for analysis. Each mouse was tested only mice. In this experiment the mice were injected intraperitoneally with a standard antidepressant drug (imipramine: $10 \mathrm{mg} / \mathrm{kg}$, i.p.), different doses of honey samples $(10,20 \mathrm{or} 40 \% \mathrm{v} / \mathrm{v}$ ) or vehicle (saline). Honey samples or vehicle were administered orally $60 \mathrm{~min}$ before FST while the standard drug group was administered imipramine 30 min intraperitoneally before FST (Dunn and Swiergiel, 2005).

\section{Statistical analysis}

All data are presented as mean \pm SEM. The results were analyzed by One way analysis of variance (ANOVA) and post hoc tests (Student's -Newman-Keuls) were carried out to determine the source of significant main effect using GraphPad InStat $\mathbb{R}$ Biostatistics software (GraphPad Software, Inc., La Jolla, USA). The level of significance for all tests was set at $\mathrm{p}<0.05$.

\section{Results \\ Novelty- Induced Behavior (NIB) (Locomotion, Rearing and Grooming)}

Locomotor activity, rearing and grooming (Figures 3.1a-c and Table 3.1) were investigated for the behavioral studies. All the honey samples decreased not only the locomotor activity, but also the number of rearing and grooming when compared to vehicle-treated group. Similarly, it was observed that amphetamine-induced novelty induced behaviors were significantly inhibited by the administration of some honey samples (Figures 3.1.1a-c) animals treated with amphetamine. 


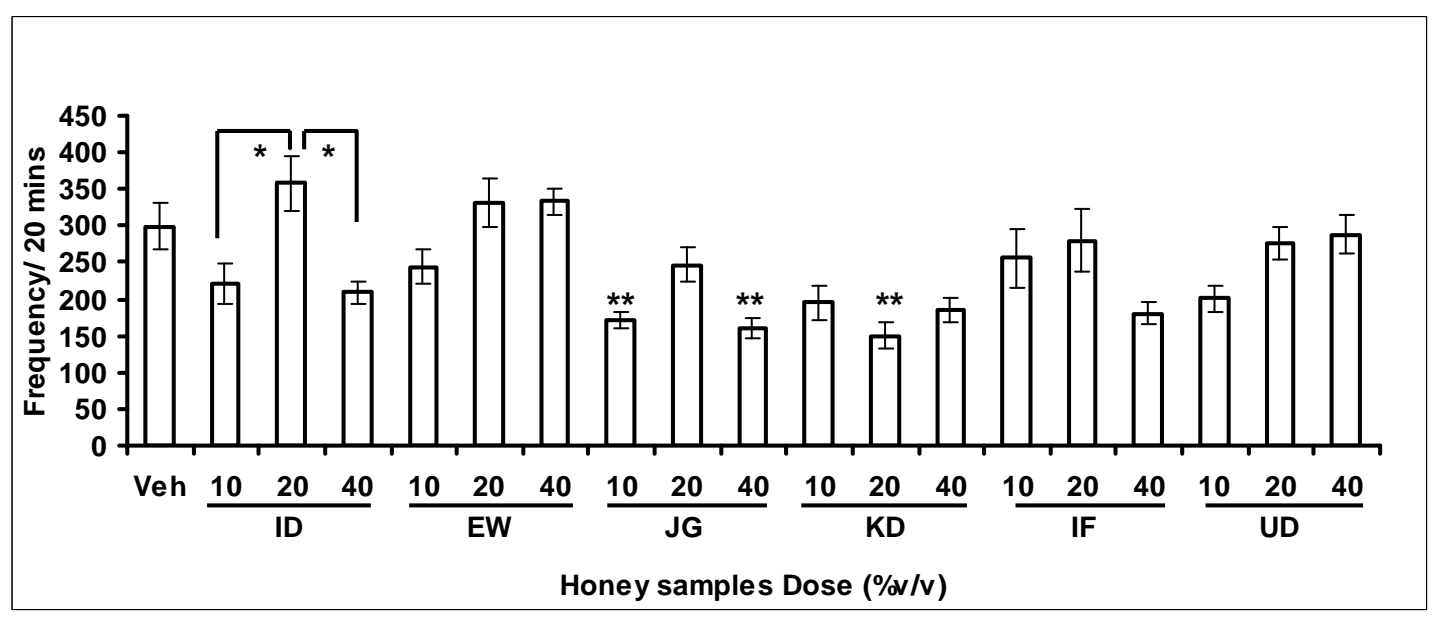

Figure 3.1a. Effect of oral administration of honey [ID: Idanre; EW: Ewu; JG: Jigawa; KD: Kaduna; IF: Ife; UD: Umudike] samples on locomotor activity in mice. The graph represents the effects on locomotor activity after administration of samples $(10,20$ or $40 \% \mathrm{v} / \mathrm{v})$ or vehicle (control). Values are presented as Mean \pm S.E.M., $(\mathrm{n}=5-8)$. Locomotor activity was significantly $\left(\mathrm{F}_{18,106)}=5.795, \mathrm{p}<0.0001\right)$ reduced by honey samples and post hoc analysis revealed the significant effect with administration of JG and KD honey samples. ${ }^{*} \mathrm{p}<0.05$ showed comparison within the group and $* * \mathrm{p}<0.05$ showed significant effect when compared with vehicle-treated group.

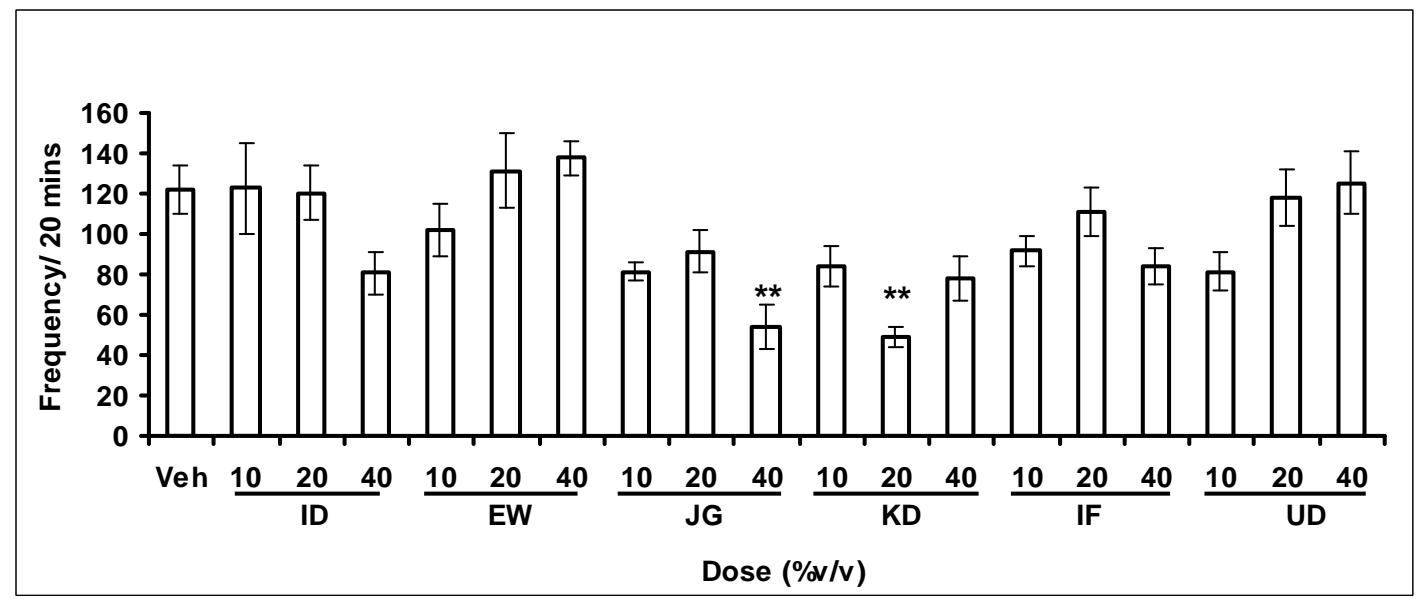

Figure 3.1b. Effect of oral administration of honey [ID: Idanre; EW: Ewu; JG: Jigawa; KD: Kaduna; IF: Ife; UD: Umudike] samples on rearing activity in mice. The graph represents the effects on rearing activity after administration of honey samples $(10,20$ or $40 \% \mathrm{~V} / \mathrm{v})$ or vehicle (control). Values are presented as Mean \pm S.E.M., $(\mathrm{n}=5-8)$. Rearing activity was significantly $\left(\mathrm{F}_{(18,106)}=4.022, \mathrm{p}<0.0001\right)$.reduced by honey samples as revealed by ANOVA and post hoc analysis showed this significant effect was due to the effects of both JG and KD honey samples when compared with the vehicle-treated group (control). $* * \mathrm{p}<0.05$ when compared with vehicle-treated group. 


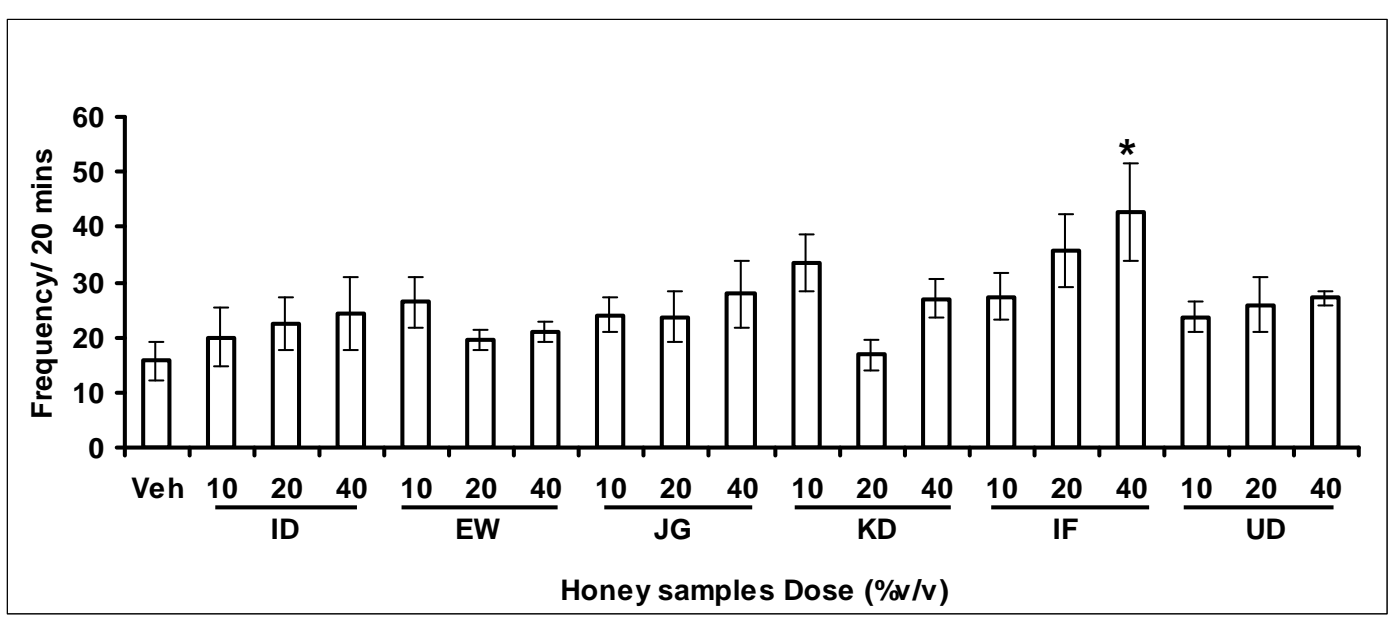

Figure 3.1c. Effect of oral administration of honey samples on grooming behavior in mice. The graph represents the effects on grooming behavior after administration of honey [ID: Idanre; EW: Ewu; JG: Jigawa; KD: Kaduna; IF: Ife; UD: Umudike] samples $(10,20$ or $40 \% \mathrm{v} / \mathrm{v})$ or vehicle (control). Values are presented as Mean \pm S.E.M., ( $\mathrm{n}=5-8)$. Grooming behavior was increased significantly $\left(\mathrm{F}_{(18,106)}=1.936, \mathrm{p}=0.022\right)$ by honey sample (IF) when compared with vehicletreated group (control). ${ }^{*} \mathrm{p}<0.05$ compared with vehicle-treated group.

Table 3.1: Effect of honey samples oral administration on Novelty-induced behaviors (locomotor, rearing and grooming behaviors) in mice at 10 minute time intervals. Values are presented as Mean \pm S.E.M. $(n=5-8) .{ }^{*} \mathrm{p}<0.05,{ }^{*}{ }^{\mathrm{p}}<0.01,{ }^{\#} \mathrm{p}<0.001$ compared to vehicle-treated group.

\begin{tabular}{|c|c|c|c|c|c|c|c|}
\hline \multirow[b]{3}{*}{ Veh } & \multicolumn{2}{|c|}{ Locomotion } & \multicolumn{2}{|c|}{ Rearing } & \multicolumn{2}{|c|}{ Grooming } & \\
\hline & $1 \mathrm{st} 10 \mathrm{~min}$ & 2nd $10 \mathrm{~min}$ & $1 \mathrm{st} 10 \mathrm{~min}$ & 2nd $10 \mathrm{~min}$ & $1 \mathrm{st} 10 \mathrm{~min}$ & 2nd $10 \mathrm{~min}$ & \\
\hline & $207.3 \pm 15.2$ & $91.7 \pm 18.3$ & $87.0 \pm 7.0$ & $35.0 \pm 6.7$ & $6.0 \pm 2.3$ & $9.7 \pm 1.7$ & $\mathrm{n}=6$ \\
\hline ID10 & $151.6 \pm 14.9 *$ & $70.0 \pm 16.0$ & $77.6 \pm 12.1$ & $45.0 \pm 11.8$ & $7.0 \pm 2.4$ & $13.0 \pm 3.4$ & $\mathrm{n}=5$ \\
\hline ID20 & $227.8 \pm 24.7$ & $130.2 \pm 12.8$ & $73.8 \pm 8.9$ & $46.4 \pm 5.3$ & $9.4 \pm 2.0$ & $13.0 \pm 2.9$ & $\mathrm{n}=5$ \\
\hline ID40 & $156.2 \pm 7.9^{*}$ & $53.4 \pm 8.9$ & $57.0 \pm 5.5^{*}$ & $23.6 \pm 5.5$ & $11.2 \pm 3.9$ & $13.0 \pm 2.8$ & $\mathrm{n}=5$ \\
\hline EW10 & $181.6 \pm 11.2$ & $62.2 \pm 12.1$ & $75.0 \pm 10.0$ & $26.8 \pm 5.2$ & $12.2 \pm 2.2$ & $14.2 \pm 2.6$ & $\mathrm{n}=5$ \\
\hline EW20 & $207.3 \pm 15.5$ & $124.0 \pm 21.3$ & $74.7 \pm 7.7$ & $56.7 \pm 11.4$ & $5.3 \pm 1.0$ & $14.2 \pm 1.9$ & $\mathrm{n}=6$ \\
\hline EW40 & $204.5 \pm 13.1$ & $128.3 \pm 11.3$ & $82.3 \pm 5.4$ & $55.3 \pm 6.2$ & $6.8 \pm 0.8$ & $14.2 \pm 1.1$ & $\mathrm{n}=6$ \\
\hline JG10 & $130.2 \pm 6.8^{*}$ & $40.8 \pm 5.0$ & $56.6 \pm 6.0$ & $24.8 \pm 4.4$ & $10.4 \pm 0.6$ & $13.6 \pm 3.0$ & $\mathrm{n}=5$ \\
\hline$J G 20$ & $164.2 \pm 17.6^{*}$ & $82.8 \pm 9.7$ & $58.0 \pm 6.6$ & $33.2 \pm 7.7$ & $9.4 \pm 2.5$ & $14.2 \pm 2.3$ & $\mathrm{n}=5$ \\
\hline$J G 40$ & $117.4 \pm 11.2^{* *}$ & $43.6 \pm 7.9$ & $34.2 \pm 5.3^{* *}$ & $20.2 \pm 5.7$ & $14.4 \pm 3.4$ & $13.4 \pm 3.4$ & $\mathrm{n}=5$ \\
\hline KD10 & $123.0 \pm 14.7^{*}$ & $71.8 \pm 16.6$ & $50.0 \pm 8.4^{*}$ & $34.2 \pm 5.5$ & $17.2 \pm 2.6^{*}$ & $16.4 \pm 3.0$ & $\mathrm{n}=5$ \\
\hline KD20 & $106.4 \pm 13.7^{* *}$ & $44.0 \pm 10.0$ & $33.8 \pm 5.2^{* *}$ & $15.6 \pm 3.9$ & $7.6 \pm 1.4$ & $9.2 \pm 1.9$ & $\mathrm{n}=5$ \\
\hline KD40 & $115.7 \pm 7.8^{* *}$ & $70.3 \pm 12.8$ & $49.2 \pm 6.3^{*}$ & $28.7 \pm 6.6$ & $13.3 \pm 2.2$ & $13.7 \pm 2.2$ & $\mathrm{n}=6$ \\
\hline IF10 & $165.0 \pm 23.1$ & $90.8 \pm 20.5$ & $55.6 \pm 6.2$ & $36.0 \pm 6.4$ & $11.8 \pm 2.0$ & $15.6 \pm 3.2$ & $\mathrm{n}=5$ \\
\hline IF20 & $166.8 \pm 18.6$ & $113.3 \pm 24.3$ & $65.0 \pm 5.2$ & $45.7 \pm 9.0$ & $15.7 \pm 3.7$ & $20.2 \pm 3.3$ & $\mathrm{n}=6$ \\
\hline IF40 & $106.0 \pm 13.0^{\#}$ & $74.2 \pm 18.6$ & $49.7 \pm 4.7^{*}$ & $34.3 \pm 7.2$ & $14.5 \pm 2.6$ & $28.2 \pm 8.6$ & $\mathrm{n}=6$ \\
\hline UD10 & $136.3 \pm 13.9 *$ & $65.0 \pm 11.2$ & $53.0 \pm 6.4^{*}$ & $28.5 \pm 6.7$ & $10.5 \pm 1.5$ & $13.2 \pm 1.5$ & $\mathrm{n}=6$ \\
\hline UD20 & $189.1 \pm 15.8$ & $87.0 \pm 12.1$ & $72.6 \pm 7.2$ & $45.1 \pm 7.1$ & $11.0 \pm 2.1$ & $14.9 \pm 3.3$ & $\mathrm{n}=8$ \\
\hline UD40 & $172.9 \pm 17.6$ & $115.4 \pm 11.6$ & $68.9 \pm 9.5$ & $56.3 \pm 7.1$ & $12.4 \pm 0.6$ & $14.7 \pm 1.1$ & $\mathrm{n}=7$ \\
\hline
\end{tabular}


Effects on amphetamine-induced NIB:

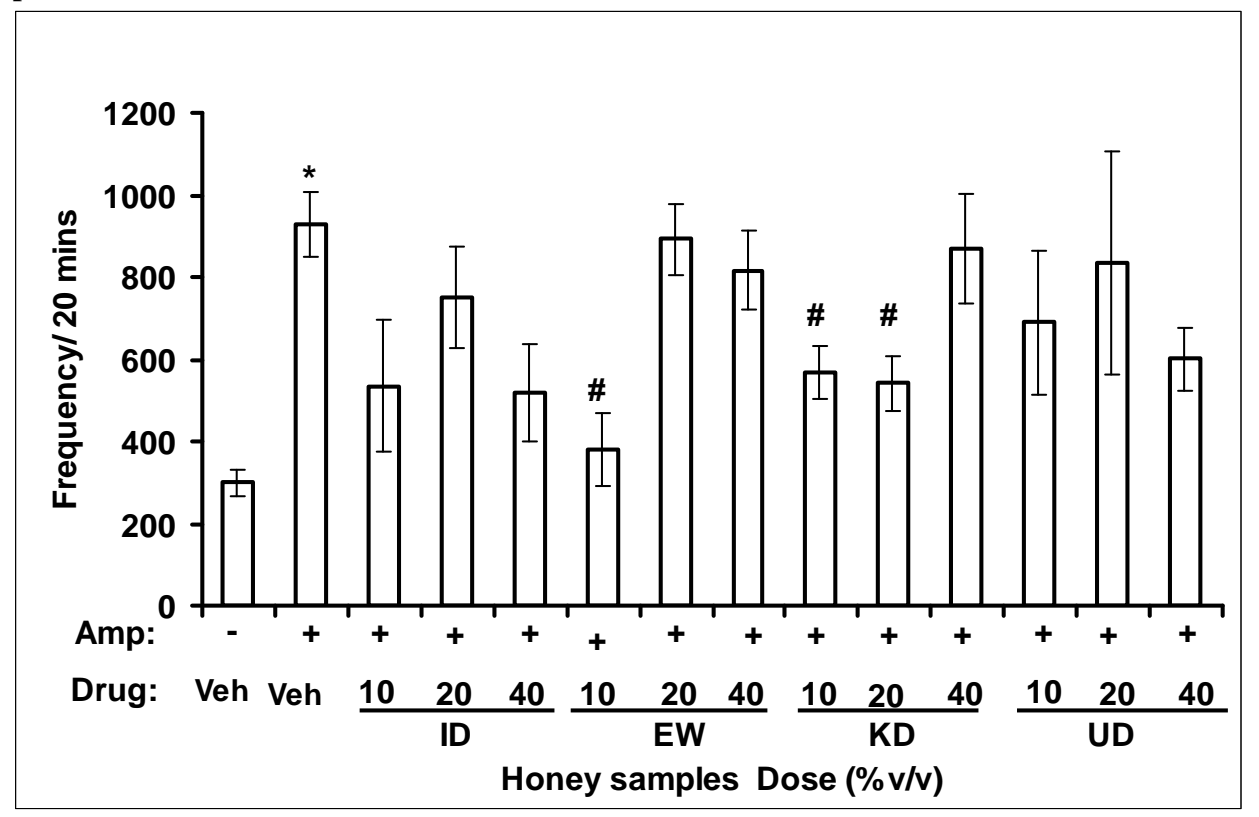

Figure 3.1.1a. Effects of honey samples on amphetamine-induced locomotor activity in mice. Mice were administered [ID: Idanre; EW: Ewu; KD: Kaduna; UD: Umudike] honey samples $(10,20$ or $40 \% \mathrm{v} / \mathrm{v}, 10 \mu \mathrm{l} / \mathrm{g}$ body weight) $1 \mathrm{~h}$ or vehicle (saline) prior to administration of amphetamine $(2 \mathrm{mg} / \mathrm{kg}$, i.p.). Locomotor counts were summed over $20 \mathrm{~min}$ and data are represented as mean \pm S.E.M, $n=6$ per group. $\left(\mathrm{F}_{13,83}=2.418, \mathrm{p}=0.009\right.$; Veh vs Amp, $\left.{ }^{*} \mathrm{p}<0.05\right)$. ${ }^{*} \mathrm{p}<0.05$ compared to vehicle (saline) treated control; ${ }^{\#} \mathrm{p}<0.05$ as compared to amphetamine-treated mice alone. Amp: amphetamine.

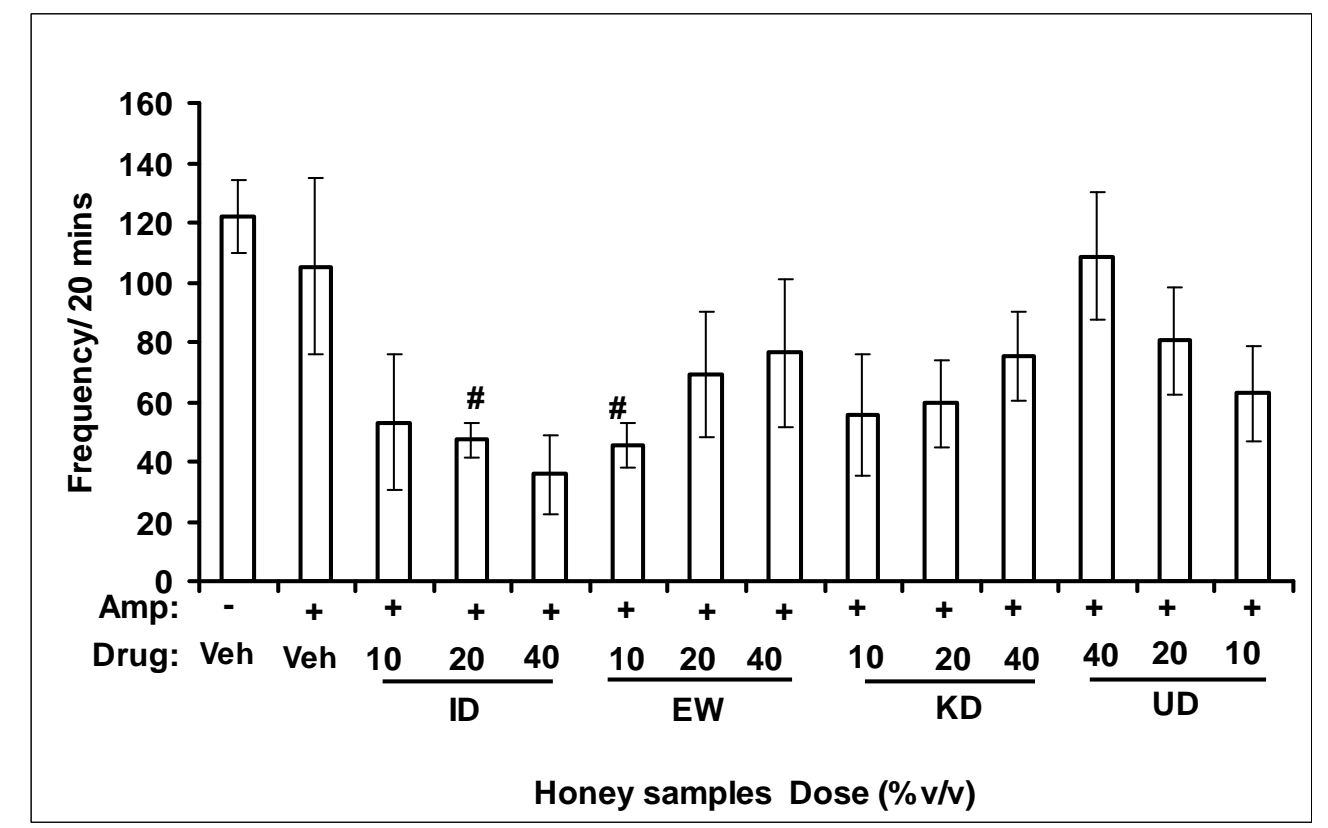

Figure 3.1.1b. Effects of honey samples on amphetamine influence on rearing activity in mice. Mice were administered [ID: Idanre; EW: Ewu; KD: Kaduna; UD: Umudike] honey samples $(10,20$ or $40 \% \mathrm{v} / \mathrm{v}, 10 \mu \mathrm{l} / \mathrm{g}$ body weight) $1 \mathrm{~h}$ or vehicle (saline) prior to administration of amphetamine $(2 \mathrm{mg} / \mathrm{kg}$, i.p.). Frequency of rearing behavior was determined during the 20 min time period and data are represented as mean \pm S.E.M, $n=6$ per group. $\left(\mathrm{F}_{13,83}=1.942, \mathrm{p}=0.0396\right) .{ }^{\#} \mathrm{p}<0.05$ as compared to amphetamine-treated mice alone. Amp: amphetamine. 


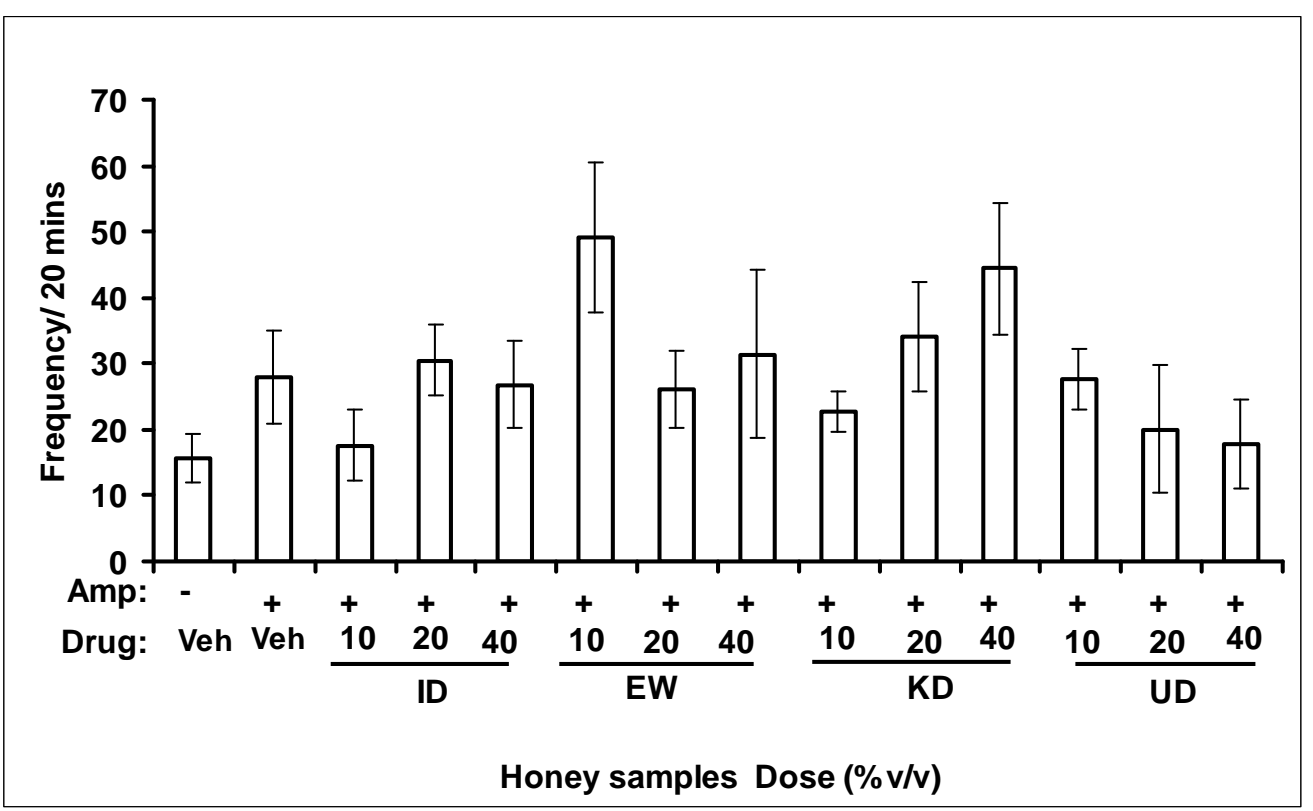

Figure 3.1.1c: Effects of honey samples on amphetamine influence on grooming behavior in mice. Mice were administered [ID: Idanre; EW: Ewu; KD: Kaduna; UD: Umudike] honey samples (10, 20 or $40 \% \mathrm{v} / \mathrm{v}, 10 \mu \mathrm{l} / \mathrm{g}$ body weight) $1 \mathrm{~h}$ or vehicle (saline) prior to administration of amphetamine $(2 \mathrm{mg} / \mathrm{kg}$, i.p.). Frequency of grooming behavior was determined during the $20 \mathrm{~min}$ time period and data are represented as mean \pm S.E.M, $n=6$ per group. $\left(\mathrm{F}_{13,83}=1.610, \mathrm{p}=0.1031\right)$. Amp: amphetamine.

\section{Effects of Honey samples on pentobarbital-induced hypnosis in mice}

Effects of pre-treatment with honey samples on the sleep latency and duration induced by pentobarbital were as shown in Figures 3.2a and 3.2b respectively. Results showed that honey samples at doses administered had no significant effects on sleep latency, however, diazepam (positive control) decreased the sleep latency significantly. The results further showed that honey sample from Umudike (UD) at dose of $10 \% \mathrm{v} / \mathrm{v}$ and diazepam significantly increased sleep duration while samples from Ewu (EW) and Jigawa (JG) at the dose of $10 \% \mathrm{v} / \mathrm{v}$ significantly decreased the sleep duration. The other honey samples had no significant effects on sleep duration.

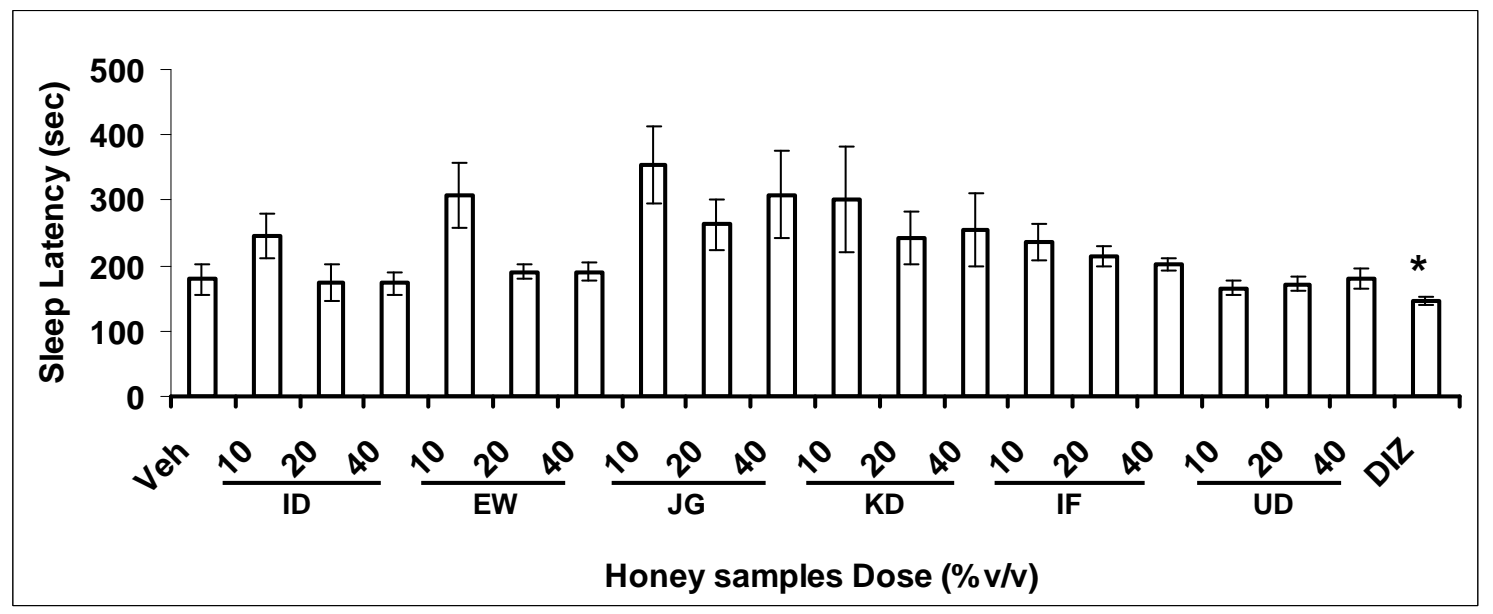

Figure 3.2a: Effects on sleep latency of mice induced by pentobarbital $(40 \mathrm{mg} / \mathrm{kg}$, i.p.) administered $1 \mathrm{~h}$ after oral administration of honey [ID: Idanre; EW: Ewu; JG: Jigawa; KD: Kaduna; IF: Ife; UD: Umudike] samples $\left(10,20\right.$ or $\left.40 \%{ }^{\mathrm{v}} / \mathrm{v}\right)$, vehicle (saline) or diazepam $\left(2 \mathrm{mg} / \mathrm{kg}\right.$, i.p.). The sleep latency was expressed as the mean \pm S.E.M. $(\mathrm{n}=5-6)$. $\left(\mathrm{F}_{19,109}=2.20\right.$, $\mathrm{p}<0.05),{ }^{*} \mathrm{p}<0.05$, significant as compared to the vehicle administered group. DIZ: diazepam. 


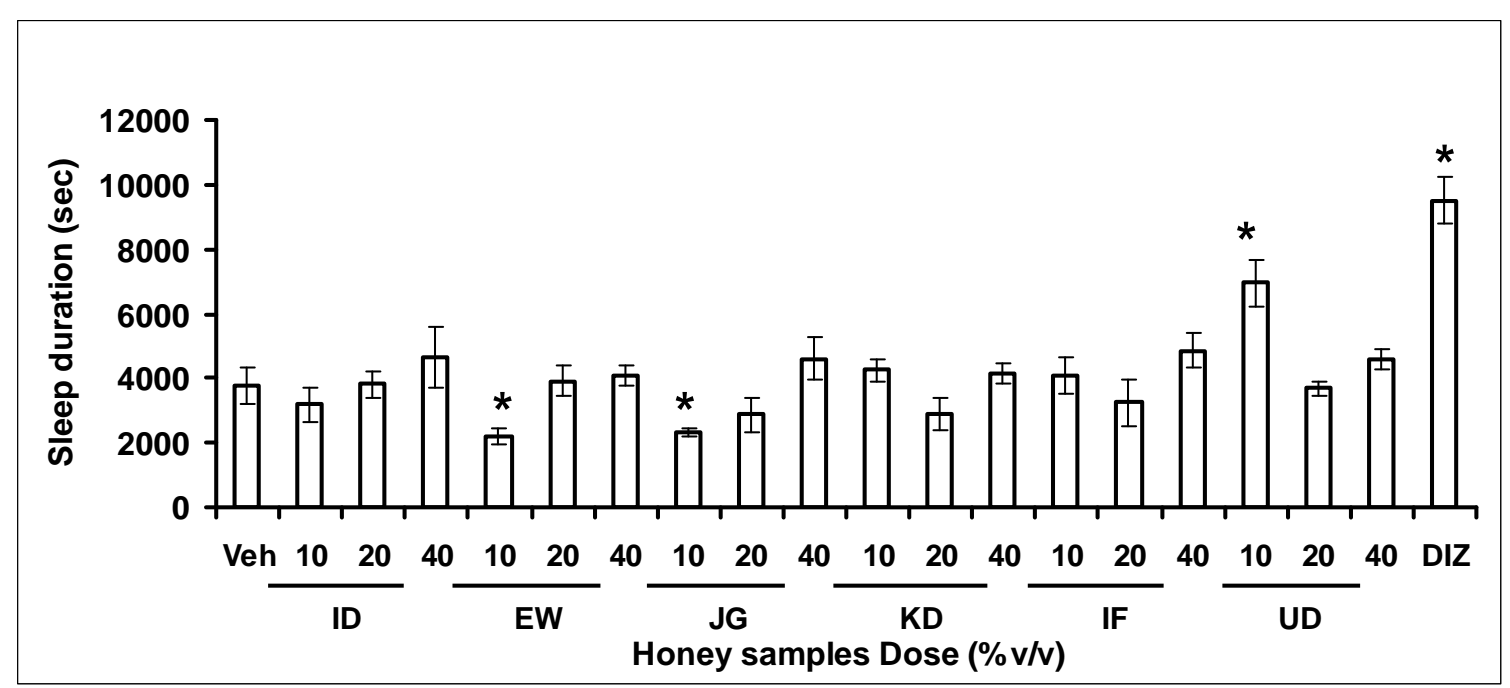

Figure 3.2b. Effects on sleep duration of mice induced by pentobarbital $(40 \mathrm{mg} / \mathrm{kg}$, i.p.) administered $1 \mathrm{~h}$ after oral administration of honey [ID: Idanre; EW: Ewu; JG: Jigawa; KD: Kaduna; IF: Ife; UD: Umudike] samples (10, 20 or $40 \% \mathrm{v} / \mathrm{v})$, vehicle (saline) or diazepam $\left(2 \mathrm{mg} / \mathrm{kg}\right.$, i.p.). The sleep duration was expressed as the mean \pm S.E.M. $(\mathrm{n}=5-6) . \mathrm{F}_{19,}, 109=8.8$, $\mathrm{p}<0.05),{ }^{*}<0.05$ significant as compared to the vehicle administered group. DIZ: diazepam.

Nootropic effects

.Y-Maze Model (Spatial working memory)

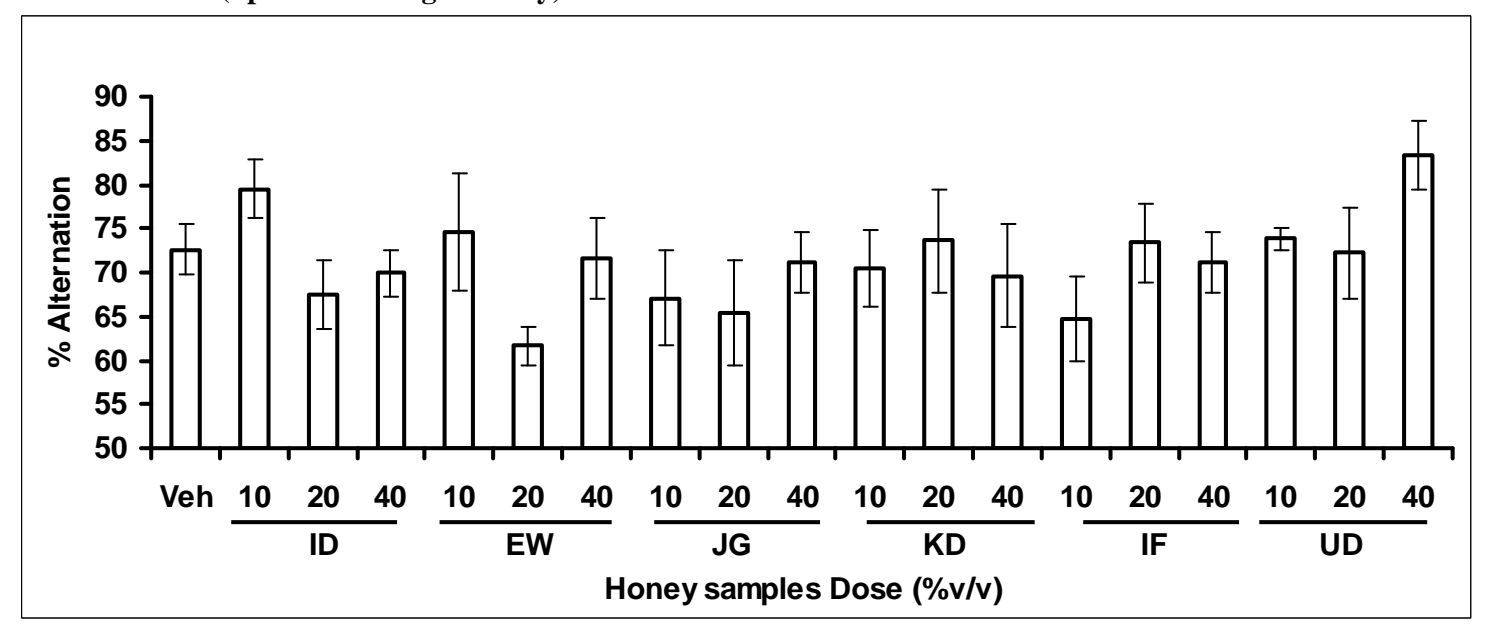

Figure 3.3.1a. Effects of oral administration of honey [ID: Idanre; EW: Ewu; JG: Jigawa; KD: Kaduna; IF: Ife; UD: Umudike] samples $(10,20$ or $40 \% \mathrm{v} / \mathrm{v})$ on the performances of mice in the spontaneous alternation behavioral test in the Y-maze $(\mathrm{n}=5-16) .\left(\mathrm{F}_{18,132}=1.344 ; \mathrm{P}=0.1745\right)$. 


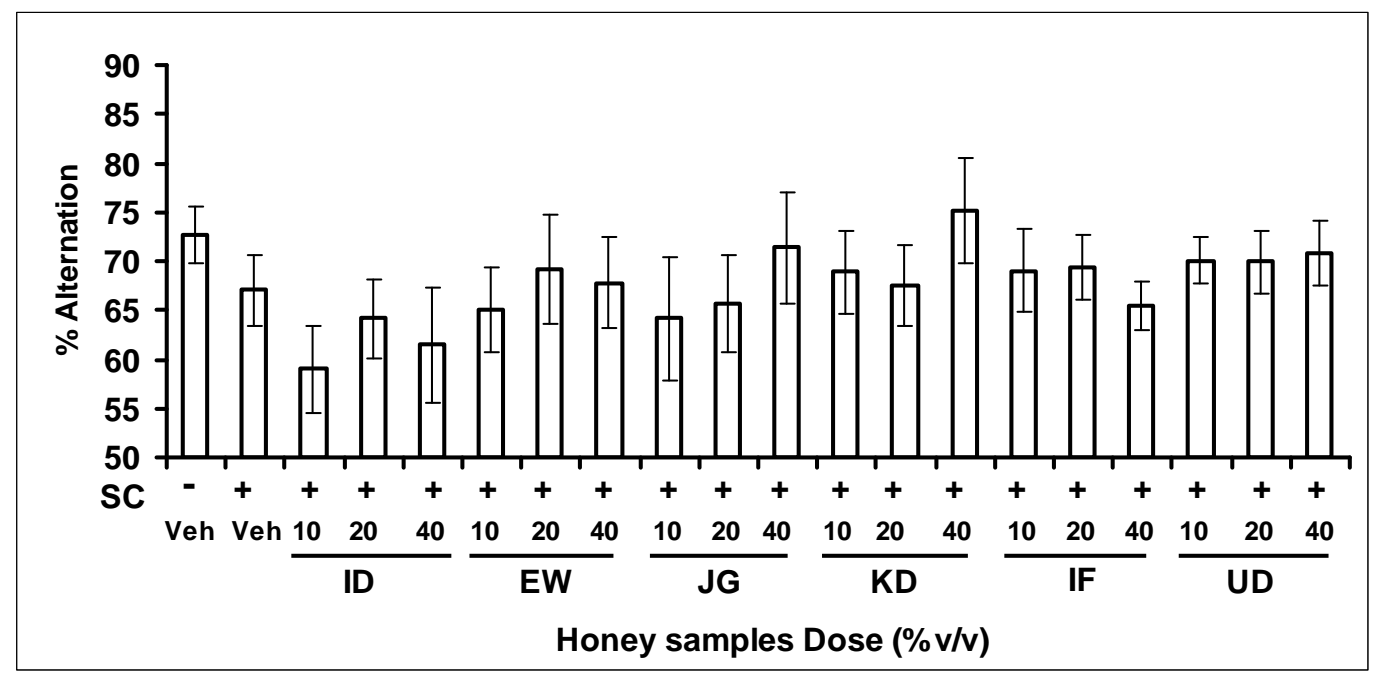

Figure 3.3.1b. Effects of oral administration of honey [ID: Idanre; EW: Ewu; JG: Jigawa; KD: Kaduna; IF: Ife; UD: Umudike] samples $(10,20$ or $40 \% \mathrm{~V} / \mathrm{v})$ on the performances of scopolamine-induced amnesic mice in the spontaneous alternation behavior test in the $\mathrm{Y}$-maze $(\mathrm{n}=5-16),\left[\left(\mathrm{F}_{19,132}=0.7872 ; \mathrm{P}=0.7177\right]\right.$. SC: Scopolamine.

Anxiolytic tests (Hole board and Elevated plus maze) Hole Board

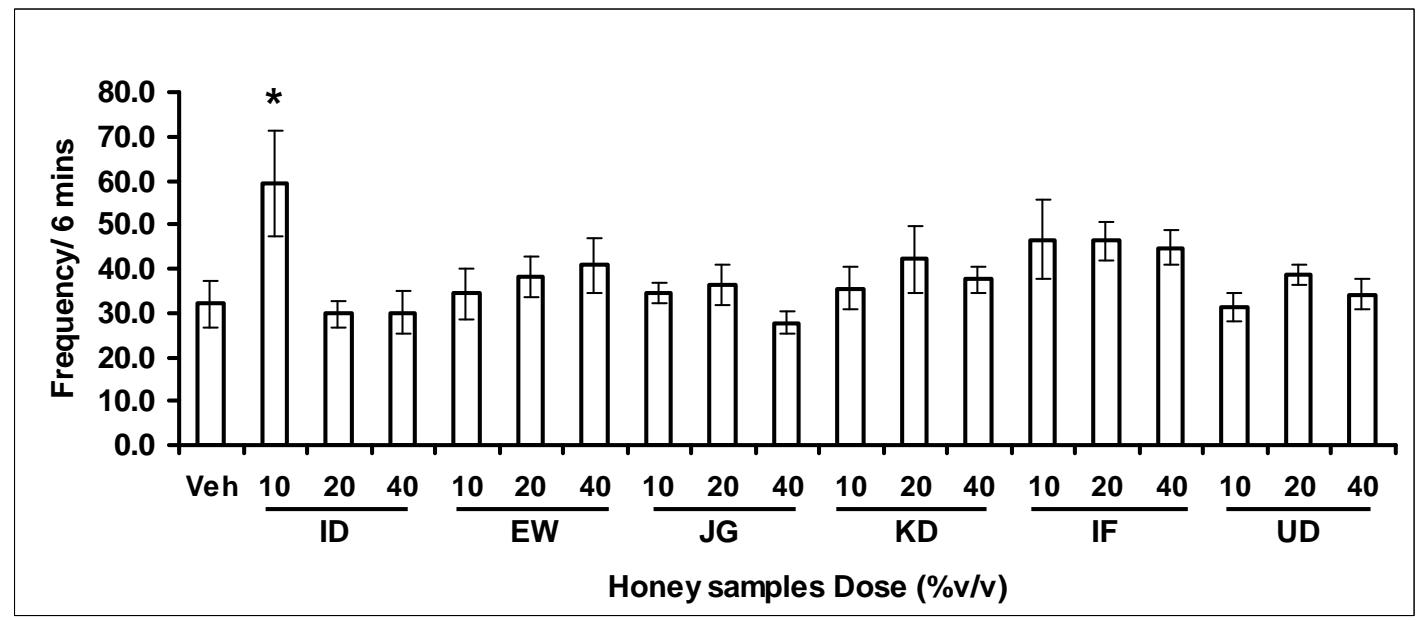

Figure 3.4.1. Effects of orally administered honey [ID: Idanre; EW: Ewu; JG: Jigawa; KD: Kaduna; IF: Ife; UD: Umudike] samples $(10,20$ or $40 \% \mathrm{v} / \mathrm{v})$ or vehicle (saline) on head dips in hole-board model. The frequency of head dips was expressed as the mean \pm S.E.M. $(\mathrm{n}=5-9)$. $\left(\mathrm{F}_{18,120}=1.9, \mathrm{p}<0.05\right) ; * \mathrm{p}<0.05$, significant as compared to the vehicle administered group. 
Elevated plus - maze

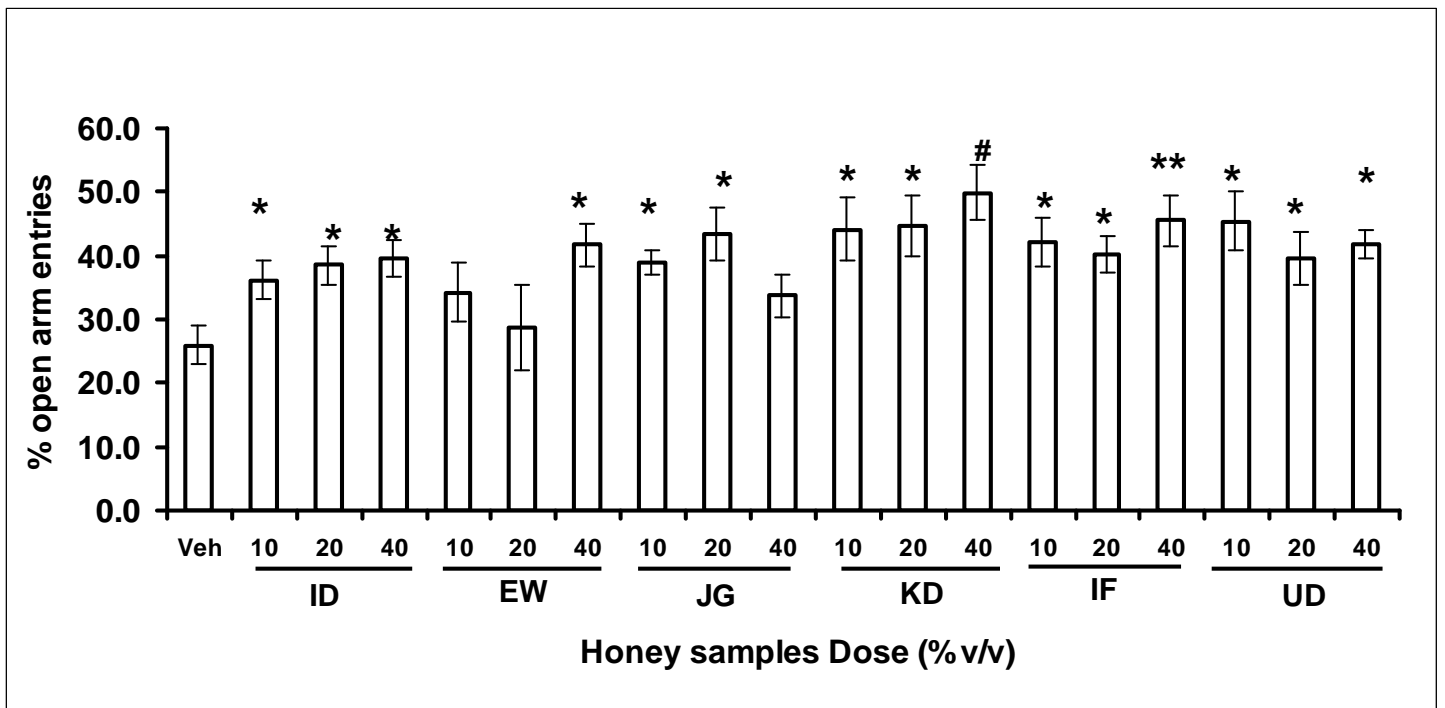

Figure 3.4.2a: Effects of orally administered honey [ID: Idanre; EW: Ewu; JG: Jigawa; KD: Kaduna; IF: Ife; UD: Umudike] samples $(10,20$ or $40 \% \mathrm{~V} / \mathrm{v}$ ) or vehicle (saline) on the percentage of open arm entries in open arms in the elevated plusmaze in mice. Open arm entries were measured for $5 \mathrm{~min}, 1 \mathrm{~h}$ after administration of different doses of honey samples. Data are expressed as mean \pm S.E.M. $(\mathrm{n}=5-7)$. $\left(\mathrm{F}_{18,114}=2.34, \mathrm{p}<0.01\right),{ }^{*} \mathrm{p}<0.05, * * \mathrm{p}<0.01$ or ${ }^{\#} \mathrm{p}<0.001$ significant as compared to the vehicle administered control group.

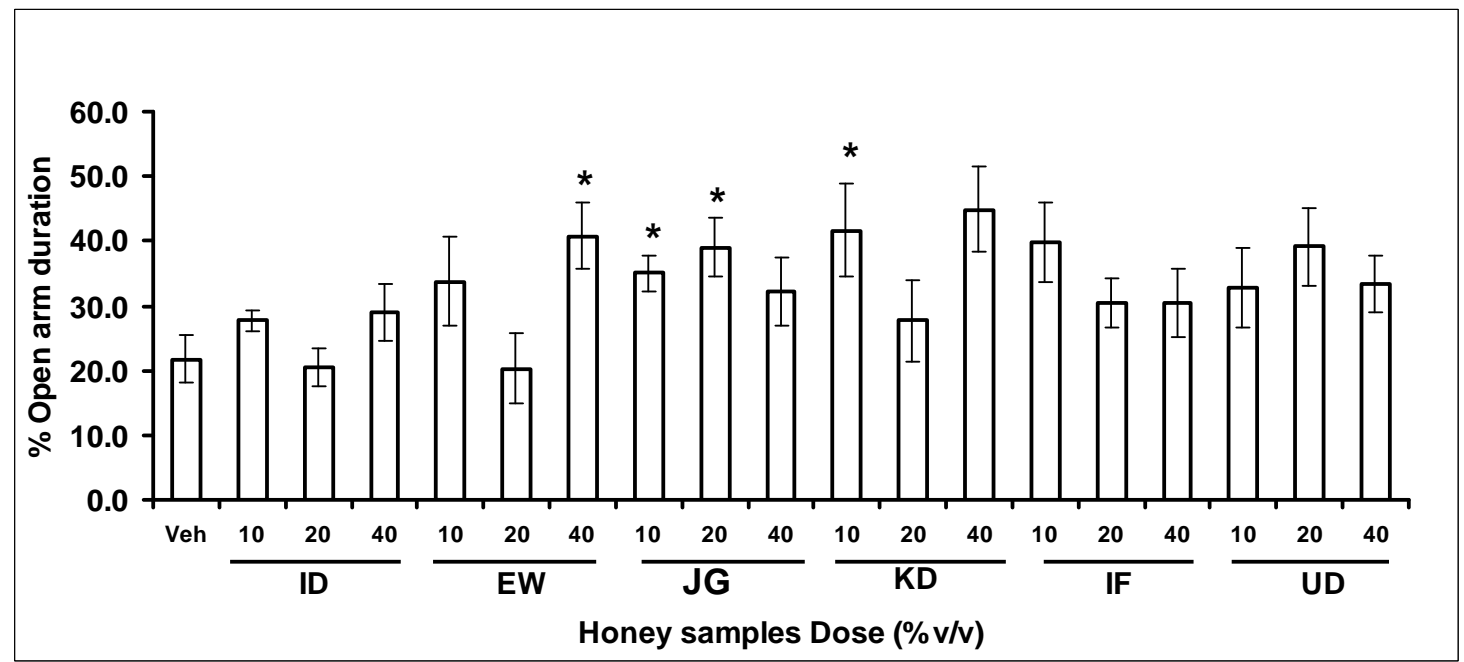

Figure 3.4.2b: Effects of orally administered [ID: Idanre; EW: Ewu; JG: Jigawa; KD: Kaduna; IF: Ife; UD: Umudike] samples $(10,20$ or $40 \% \mathrm{~V} / \mathrm{v})$ or vehicle (saline) on the percentage of open arm duration in open arms in the elevated plus-maze in mice. Open arm duration was measured for $5 \mathrm{~min}, 1 \mathrm{~h}$ after administration of different doses of honey samples. Data are expressed as mean \pm S.E.M. $(\mathrm{n}=5-7)$. $\left(\mathrm{F}_{18,114}=1.89, \mathrm{p}<0.05\right),{ }^{*} \mathrm{p}<0.05$, significant as compared to the vehicle administered control group. 


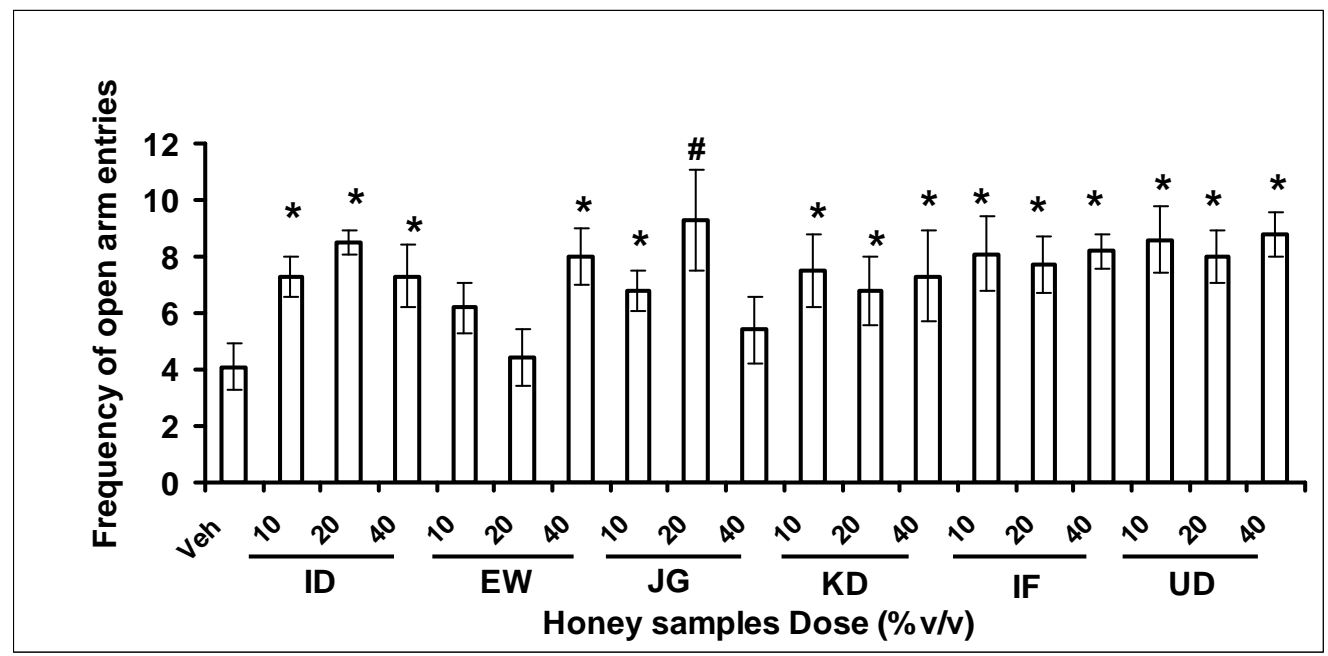

Figure 3.4.2c. Effects of orally administered honey [ID: Idanre; EW: Ewu; JG: Jigawa; KD: Kaduna; IF: Ife; UD: Umudike] samples $(10,20$ or $40 \% \mathrm{~V} / \mathrm{v})$ or vehicle (saline) on the frequency of open arm entries in open arms in the elevated plusmaze in mice. Open arm entries were measured for $5 \mathrm{~min}, 1 \mathrm{~h}$ after administration of different doses of honey samples. Data are expressed as mean \pm S.E.M. $(\mathrm{n}=5-7)$. $\left(\mathrm{F}_{18,114}=2.34, \mathrm{p}<0.01\right),{ }^{*} \mathrm{p}<0.05, * * \mathrm{p}<0.01$ or ${ }^{*} \mathrm{p}<0.001$ significant as compared to the vehicle administered control group.

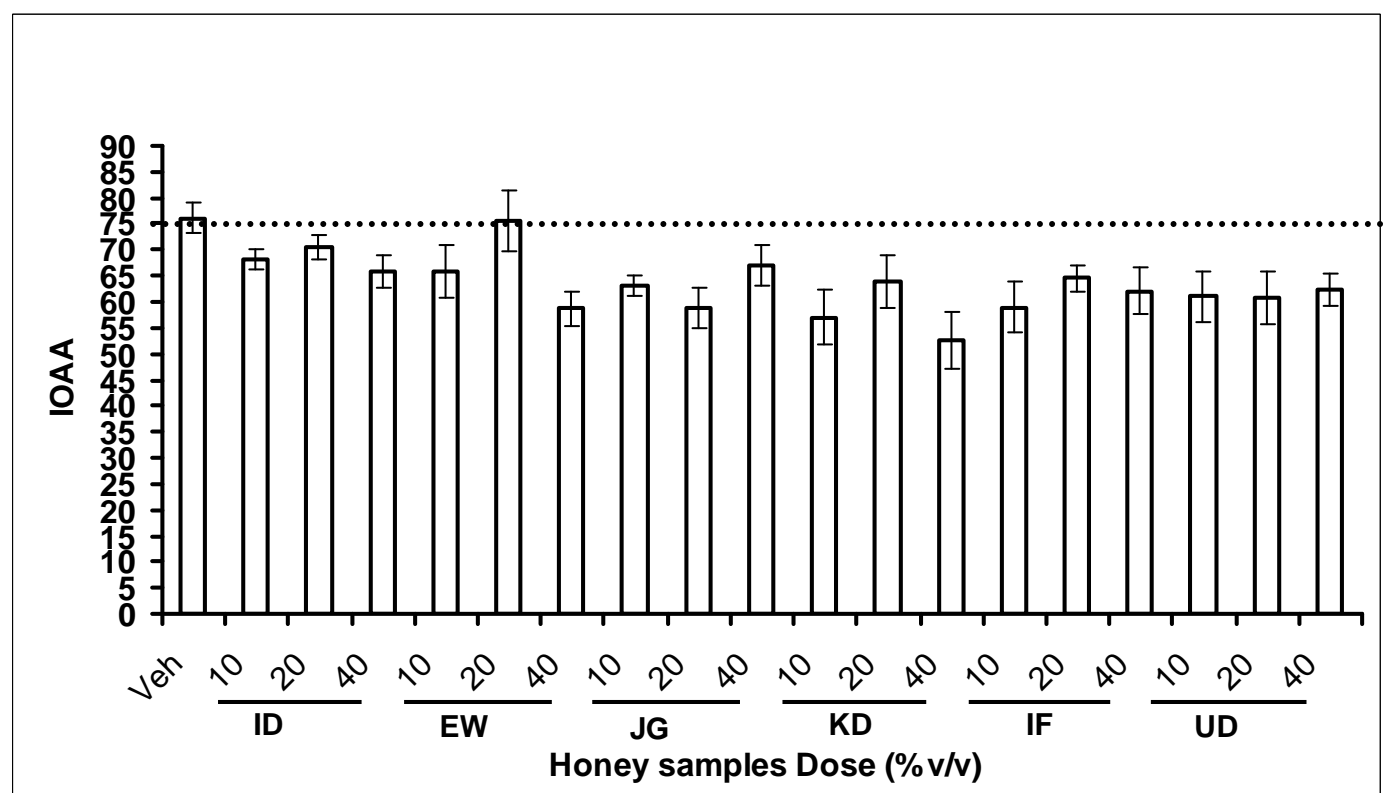

Figure 3.4.2d. Effects of orally administered honey [ID: Idanre; EW: Ewu; JG: Jigawa; KD: Kaduna; IF: Ife; UD: Umudike] samples $(10,20$ or $40 \% \mathrm{v} / \mathrm{v}$ ) or vehicle (saline) on the index of open arm avoidance (IOAA) in the elevated plus-maze in mice. IOAA $=100-(\%$ Time spent in open arms $+\%$ entries into open arms $) / 2$. If results is at least 10 point $<$ than vehicle, the sample is anxiolytic, conversely if result is at least 10 points $>$ saline (Vehicle), then the sample is anxiogenic. Thus, all the honey samples doses administered showed anxiolytic effects except (ID: 20 and $10 \%{ }^{\mathrm{V}} / \mathrm{v}$; EW: $20 \% \mathrm{~V} / \mathrm{v} ; \mathrm{JG}: 40 \% \mathrm{~V} / \mathrm{v}$ ) when compared to the vehicle-treated group. 
Anticonvulsant effects

Table 3.2: The anticonvulsant effects of honey samples in pictrotoxin seizure model in mice

\begin{tabular}{|c|c|c|c|c|c|c|}
\hline & Onset of Clonic (s) & Onset of Tonic (s) & $\begin{array}{l}\text { Number of } \\
\text { Convulsions }\end{array}$ & $\begin{array}{l}\text { No. } \\
\text { death/No. } \\
\text { used }\end{array}$ & $\begin{array}{l}\text { Protection } \\
(\%)\end{array}$ & \\
\hline Veh & $136.2 \pm 13.0$ & $196.2 \pm 14.5$ & $11.7 \pm 0.9$ & $6.0 / 6.0$ & 0.0 & $\mathrm{n}=6$ \\
\hline ID40 & $150.5 \pm 12.5$ & $179.2 \pm 20.2$ & $15.7 \pm 1.4$ & $6.0 / 6.0$ & 0.0 & $\mathrm{n}=6$ \\
\hline ID20 & $138.4 \pm 3.2$ & $169.2 \pm 3.2$ & $11.8 \pm 1.4$ & $5.0 / 5.0$ & 0.0 & $\mathrm{n}=5$ \\
\hline ID10 & $129.7 \pm 12.6$ & $154.5 \pm 9.0$ & $12.7 \pm 1.8$ & $6.0 / 6.0$ & 0.0 & $\mathrm{n}=6$ \\
\hline EW40 & $175.0 \pm 11.4$ & $202.3 \pm 13.7$ & $19.8 \pm 2.1$ & $6.0 / 6.0$ & 0.0 & $\mathrm{n}=6$ \\
\hline EW20 & $161.0 \pm 15.9$ & $208.2 \pm 25.1$ & $14.4 \pm 1.4$ & $5.0 / 5.0$ & 0.0 & $\mathrm{n}=6$ \\
\hline EW10 & $166.8 \pm 11.7$ & $217.2 \pm 16.7$ & $13.3 \pm 1.7$ & $6.0 / 6.0$ & 6.0 & $\mathrm{n}=6$ \\
\hline JG40 & $149.4 \pm 8.3$ & $192.2 \pm 11.9$ & $10.4 \pm 2.1$ & $1.0 / 6.0$ & 16.7 & $\mathrm{n}=5$ \\
\hline JG 20 & $179.4 \pm 28.2$ & $208.2 \pm 24.9$ & $16.4 \pm 3.0$ & $1.0 / 6.0$ & 16.7 & $\mathrm{n}=5$ \\
\hline JG10 & $125.7 \pm 1.3$ & $165.3 \pm 12.9$ & $12.8 \pm 1.2$ & $6.0 / 6.0$ & 0.0 & $\mathrm{n}=6$ \\
\hline KG40 & $136.5 \pm 9.7$ & $191.7 \pm 12.0$ & $13.2 \pm 0.7$ & $6.0 / 6.0$ & 0.0 & $\mathrm{n}=6$ \\
\hline KD20 & $150.3 \pm 17.0$ & $196.7 \pm 23.9$ & $11.0 \pm 2.2$ & $6.0 / 6.0$ & 0.0 & $\mathrm{n}=6$ \\
\hline KD10 & $132.2 \pm 5.0$ & $166.8 \pm 8.4$ & $13.0 \pm 0.9$ & $5.0 / 5.0$ & 0.0 & $\mathrm{n}=5$ \\
\hline IF40 & $155.0 \pm 19.4$ & $194.5 \pm 20.4$ & $18.0 \pm 1.8$ & $6.0 / 6.0$ & 0.0 & $\mathrm{n}=6$ \\
\hline IF20 & $178.2 \pm 18.8$ & $215.8 \pm 24.6$ & $18.3 \pm 2.2$ & $6.0 / 6.0$ & 0.0 & $\mathrm{n}=6$ \\
\hline IF10 & $140.3 \pm 8.6$ & $185.0 \pm 9.4$ & $11.5 \pm 0.6$ & $6.0 / 6.0$ & 0.0 & $\mathrm{n}=6$ \\
\hline UD40 & $355.2 \pm 42.5^{*}$ & $536.5 \pm 143.5^{*}$ & $7.5 \pm 2.2^{*}$ & $3.0 / 6.0$ & 50.0 & $\mathrm{n}=6$ \\
\hline UD20 & $632.7 \pm 150.7 *$ & $1019.5 \pm 179.2 *$ & $3.3 \pm 1.0^{*}$ & $4.0 / 6.0$ & 66.7 & $\mathrm{n}=6$ \\
\hline UD10 & $1063.5 \pm 248.1^{*}$ & $1066.0 \pm 247.0^{*}$ & $4.8 \pm 1.6^{*}$ & $3.0 / 6.0$ & 50.0 & $\mathrm{n}=6$ \\
\hline DIZ & $1800.0 \pm 0.0 *$ & $1800.0 \pm 0.0 *$ & $0.0 \pm 0.0^{*}$ & $0.0 / 6.0$ & 100.0 & $\mathrm{n}=6$ \\
\hline
\end{tabular}

\section{Analgesic effects}

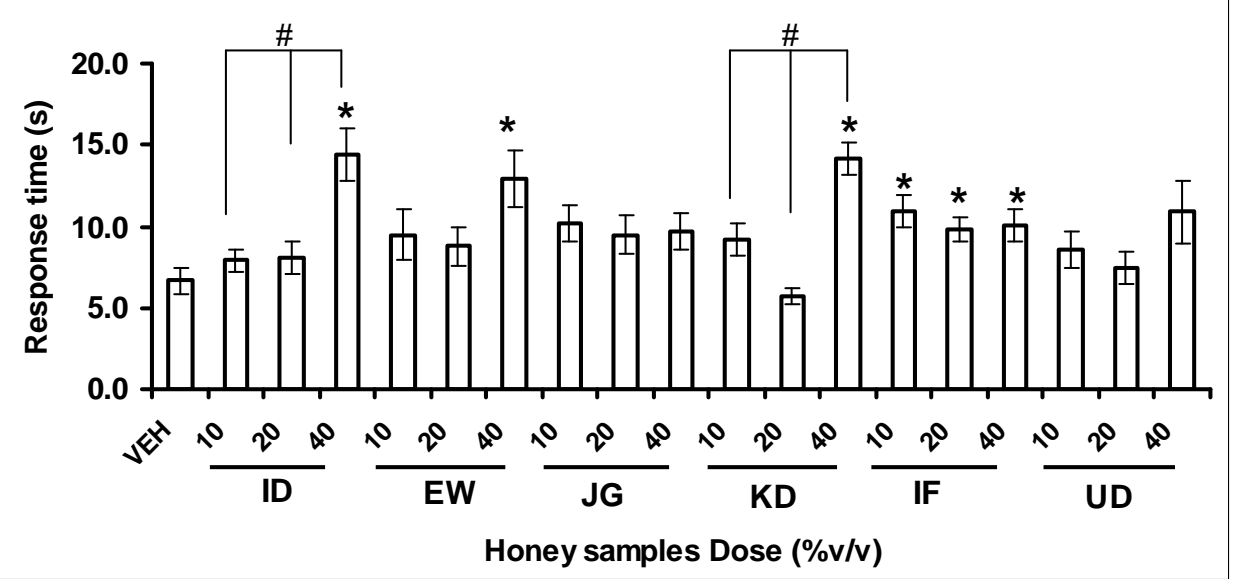

Figure 3.5.1: Effects of orally administered honey [ID: Idanre; EW: Ewu; JG: Jigawa; KD: Kaduna; IF: Ife; UD: Umudike] samples $(10,20$ or $40 \% \mathrm{v} / \mathrm{v})$ or vehicle (saline) on pain reaction time on hot plate. The pain reaction time was recorded after $1 \mathrm{~h}$ administration of different doses of honey samples. Data are expressed as mean \pm S.E.M. $(\mathrm{n}=6)$. $\left(\mathrm{F}_{18,113}=3.81\right.$, $\mathrm{p}<0.001),{ }^{*} \mathrm{p}<0.05$, significant as compared to the vehicle administered control group; ${ }^{*} \mathrm{p}<0.05$, significantly different from the doses within the same group as determined by ANOVA followed by Student's-Newman-Keul's test. 


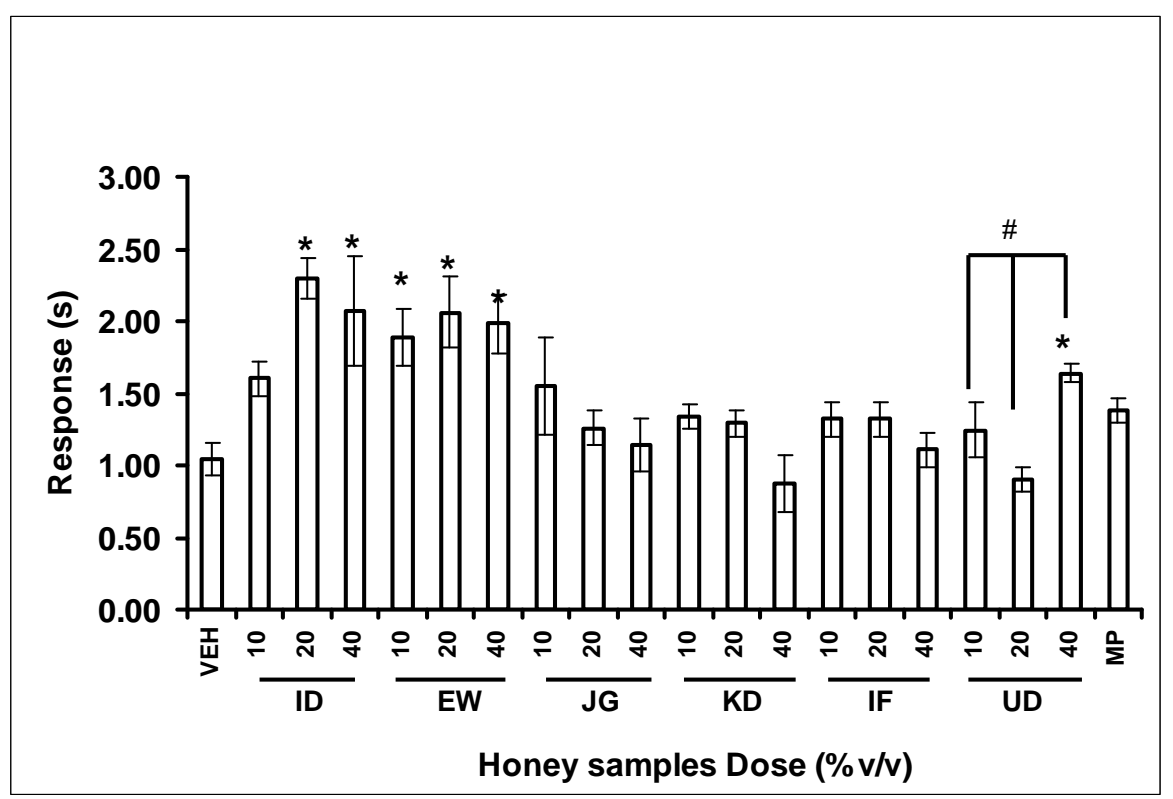

Figure 3.5.2a. Effects of orally administered honey [ID: Idanre; EW: Ewu; JG: Jigawa; KD: Kaduna; IF: Ife; UD: Umudike] samples $(10,20$ or $40 \% \mathrm{~V} / \mathrm{v})$ or vehicle (saline) on pain reaction time in tail flick test. The tail flick response time in seconds was observed $1 \mathrm{~h}$ after administration of different doses of honey samples. Morphine [MP] (10 mg/kg, i.p.) was the reference drug. Data are expressed as mean \pm S.E.M. $(n=5-6) .\left(F_{19,105}=4.94, p<0.001\right), * p<0.05$, significant as compared to the vehicle administered control group; ${ }^{\#}<0.05$, significantly different from the doses within the same group as determined by ANOVA followed by Student's-Newman-Keul's test.

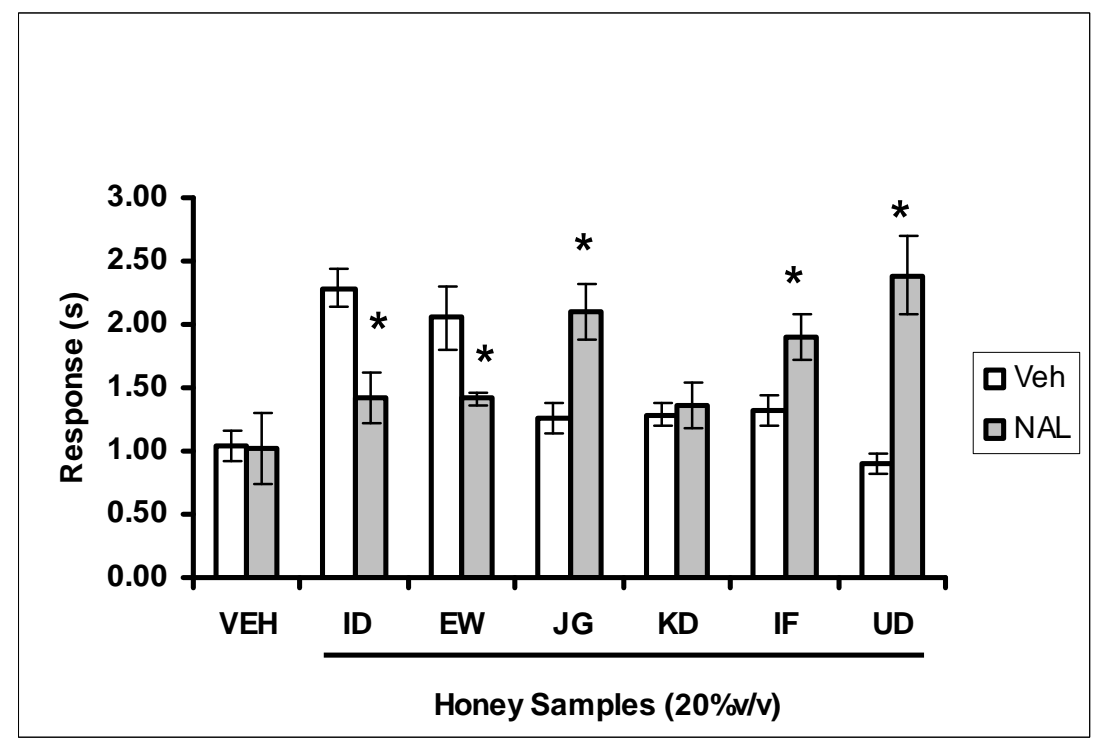

Figure 3.5.2b. Effects of orally administered honey [ID: Idanre; EW: Ewu; JG: Jigawa; KD: Kaduna; IF: Ife; UD: Umudike] samples $(20 \% \mathrm{v} / \mathrm{v})$ or vehicle (saline) alone, or with naloxone $(1 \mathrm{mg} / \mathrm{kg}$, i.p.) on pain reaction time in tail flick test. The tail flick response time in sec was observed $1 \mathrm{~h}$ after administration of different doses of honey samples alone, or with naloxone (NAL). Data are expressed as mean \pm S.E.M. $(n=5-6)$. $* \mathrm{p}<0.05$, significant as compared to the corresponding vehicle-honey administered group. 
Antidepressant

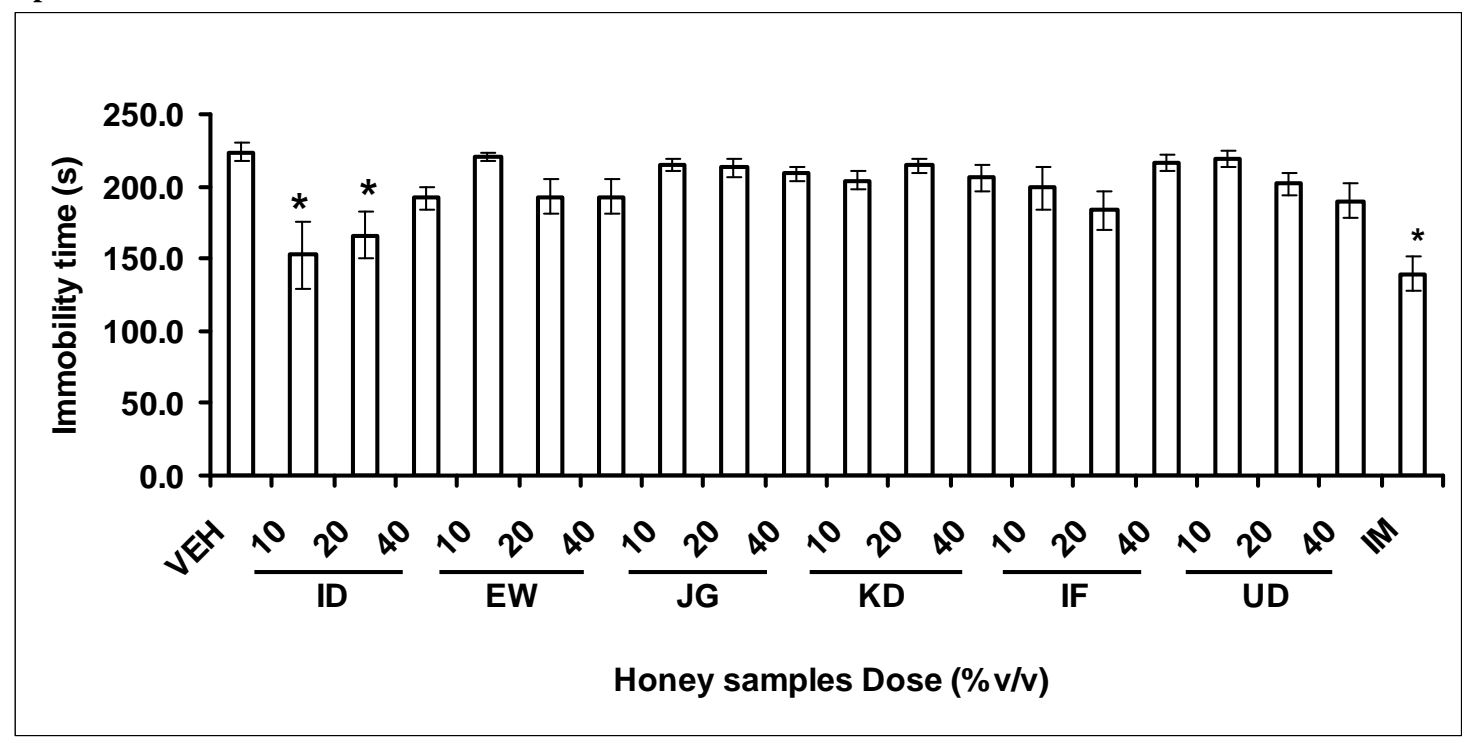

Figure 3.6: Effects of orally administered honey [ID: Idanre; EW: Ewu; JG: Jigawa; KD: Kaduna; IF: Ife; UD: Umudike] samples $(10,20$ or $40 \% \mathrm{v} / \mathrm{v})$ or vehicle (saline) on immobility time in Forced swimming test model. Imipramine [IM] $(10 \mathrm{mg} / \mathrm{kg}$, i.p. $)$ was the reference drug. Data are expressed as mean \pm S.E.M. $(\mathrm{n}=5-11) .\left(\mathrm{F}_{19,131}=5.17, \mathrm{p}<0.001\right)$, * $\mathrm{p}<0.05$, significant as compared to the vehicle administered control group as determined by ANOVA followed by Student's-Newman-Keul's test.

\section{Discussion}

In this study, the effects of honey samples were studied in several behavioral models such as novelty-induced behavior (NIB), amphetamine-induced NIB, pentobarbital-induced hypnosis, Y-maze and elevated plus maze (Nootropic models), holeboard and elevated plus maze (anxiolytic), , picrotoxin-induced convulsions test, hotplate and tail flick tests and forced swimming test to evaluate the possible neuropharmacological effects.

In novelty-induced behavioral test, locomotor activity (Fig. 3.1a), rearing (Fig. 3.1b and grooming (Fig. 3.1c) were significantly affected by the administration of honey samples in mice. Honey samples from Idanre (ID), Jigawa (JG) and Ile-Ife (IF) significantly decreased locomotion activity at the dose of $40 \% \mathrm{v} / \mathrm{v}$. All these samples decreased not only the locomotor activity, but also the number of rearing when compared to vehicle-treated group. It was observed that grooming activity was only significantly increased with administration of Kaduna (KD) and Ile-Ife (IF) samples at the doses of $10 \% \mathrm{~V} / \mathrm{v}$ and $40 \% \mathrm{~V} / \mathrm{v}$ respectively while other samples at doses administered had no significant effects on grooming behavior. Both Locomotor and rearing activities of rodents are indicative of their explorative and are also considered to be central excitatory behavior [Ajayi and Ukponmwan, 1994]. The reduction of both locomotor and rearing activities by the administration of these honey samples could be due to their central inhibitory action on excitatory neural systems such as glutamatergic and dopaminergic systems among others or their possible potentiation of the central inhibitory systems such as $\gamma$-aminobutyric acid (GABA). The results showed that these honey samples have central inhibitory effects. In order to understand at least one of the possible mechanisms of actions, the effects on amphetamine-induced NIB in four samples were investigated. The results are as shown in Figures 3.1.1a-c). It was observed that both amphetamine-induced locomotor activity was inhibited significantly by the administration of Idanre (ID), Ewu (EW) and Kaduna (KD) samples as shown in Figure 3.1.1a in comparison to animals treated with amphetamine suggesting possible involvement of dopaminergic system in the honey samples having central inhibitory effect on locomotion.

In pentobarbital-induced hypnotic test, the results obtained showed that all the honey samples had no significant effect on the pentobarbital- induced sleep latency when compared to that of vehicle-treated mice. However, only the samples from Umudike (UD) at $10 \% \mathrm{v} / \mathrm{vsignificantly} \mathrm{increased} \mathrm{the} \mathrm{pentobarbital-induced} \mathrm{sleep} \mathrm{duration} \mathrm{when} \mathrm{compared} \mathrm{to} \mathrm{that} \mathrm{of} \mathrm{vehicle-}$ treated mice. It was observed that the standard drug - diazepam also significantly increased the pentobarbital-induced hypnosis. It can therefore be inferred that only sample from Umudike (UD) has hypnotic effect in mice. The results from spontaneous alternation test using the Y-Maze showed that there was no significant effect on spatial working memory at doses used in this study (Figures 3.3.1a \&b).

Anxiety, a state of excessive fear, is characterized by motor tension, sympathetic hyperactivity, apprehension and vigilance syndromes (Sadock and Sadock, 2003). Anxiety may interfere with intelligence, psychomotor function and memory 
(Pine et al., 1999). Among the models of anxiety disorders that are used in determining anxiolytic or anxiogenic properties of substances are hole board and elevated plus maze in rodents. Hole board test is based on assumption that head-dipping of animals is inversely proportional to their anxiety state in moderately aversive environment [Bilkei-Gorzo and Gyertyan, 1996]. Therefore increased number of head dips into the holes on the board means reduced anxiety state. In this study, hole board showed that exploratory behavior was increased with the administration of honey samples but it was only the honey sample from Idanre (ID) at $10 \% \mathrm{v} / \mathrm{v}$ that showed a significant level. We therefore have to further investigate the effects of honey administration on anxiety state using the elevated-plus maze. It is well known that EPM test is used to evaluate the relative anxiety status of rats or mice. EPM, a widely used test based on the natural aversion of rodents to heights and open spaces, was originally developed by Pellow et al. (1985). The EPM situation rests on the conflict between the innate tendencies of the rodents to explore novel environments and avoid open and brightly lit areas. In this task, the animal is placed in the centre of the maze. From here, it can walk down any of the four runways. Two of the arms are well lit and open, and the other two are enclosed and dimly lit. Mice and rats prefer the closed arms but will venture out into the open arms and the amount of time spent in the open arms is noted. Generally, anxious mice or rats tend to spend little time in the open arms. Anxiolytic drugs increase the time spent in the open arms and increase the number of open arm entries during the test. In the elevated plus maze, most of the honey samples caused significant increase in both percentage open arm entries and durations as shown in figures 3.4.2a and $\mathrm{b}$. The determination of the "Index of open arm avoidance" revealed that all the honey samples at the doses administered showed anxiolytic effects except (ID: 10 and $20 \% \mathrm{~V} / \mathrm{v}$; EW: $20 \% \mathrm{v} / \mathrm{v}$ and JG: $40 \% \mathrm{v} / \mathrm{v}$ ) when compared with control (vehicle-treated group).

Picrotoxin (PTX) administration significantly increased convulsions and mortality in mice. However, with administration of honey samples, the onset of convulsions and mortality due to PTX were significantly delayed. Diazepam a standard anticonvulsant drug significantly delayed the onset of convulsions and severity induced by picrotoxin establishing its protective effects in mice. There was an increase in the onset of action and the death time of clonic seizure, with administration of the honey samples with significant effect clearly indicated with sample Umudike (UD) (Table 3.2). The number of convulsions was also significantly decreased with administration of this sample (Umudike sample). The Umudike sample also gave between 50 and $66.7 \%$ protection against PTX -induced convulsion while Jigawa sample gave $16 \%$ protection when compared with control. However, other honey samples gave no protection. The standard drug used (Diazepam, $2 \mathrm{mg} / \mathrm{kg}$, i.p) showed significant protective effects in this study. The present study provides evidence for the anticonvulsant activity of the honey samples (especially the honey obtained from Umudike in the picrotoxin model. Thus, the protective effects of this honey sample in both clonic and tonic seizures suggest that it could be useful in the alleviation of seizures.

The central analgesic effects of Nigerian honey samples were determined in hot plate and tail flick models. Both hot plate and tail immersion tests are of thermal stimuli and an increase in the reaction time is generally considered to be an important parameter for the evaluation of central antinociceptive activity (Rujjanawate et al., 2003). In hot plate test, the results obtained after oral administration of honey samples at different doses in mice showed that four honey samples have significant antinoceptive effects at the highest dose of $40 \% \mathrm{v} / \mathrm{v}$ (Fig. 3.6.1). These significant antinociceptive effects were observed with Idanre (ID), Ewu (EW), Kaduna (KD) and Ile-Ife (IF) samples. In the second model, the tail flick test, it was observed that these samples still showed significant antinociceptive effects as shown in figure 3.6.2a. They significantly increased the response time to acute pain when compared with the control group. The increase in reaction times of the mice showed that Idanre and Ewu Honey samples have the most pronounced central analgesic activities when compared to others in tail flick test model. Expectedly, the analgesic effect of morphine was significant when compared to the vehicle in both antinociceptive models. The opioid receptor involvement in this antinociceptive effect of honey in tail flick test was further investigated by using the opioid receptor antagonist, naloxone $(1 \mathrm{mg} / \mathrm{kg}$, s.c.), a non selective opioid antagonist. The results showed that naloxone significantly blocked the antinociceptive effects of samples from Idanre (ID) and Ewu (EW) showing that their antinociceptive effect is via opioid receptor. However, it was observed that naloxone potentiated the antinociceptive effects of honey samples from Jigawa (JG), Ile-Ife (IF) and Umudike (UD). The mechanisms of this potentiating interaction between Naloxone and these three honey samples are however unclear and thus require further studies. It may be suggested that these three honey samples from Jigawa (JG), Ile-Ife (IF) and Umudike (UD) may be exerting their central analgesic effects via one or more of the several non- opioid central mechanisms such as voltage-gated $\mathrm{Na}^{+}$channel blocking hypothesis, activation of noradrenergic inhibitory system and/or serotonergic systems. The cellular and neural mechanisms underlying behavioral responses elicited by drug action in the CNS e.g. pain transmission involves interplay of a number of neurotransmitters and ion channels. The difference in the mode of action of the honey samples can as well be due to difference in receptor selectivity and their chemical constituents since they are obtained from different sources. The results obtained clearly showed that Idanre, Ewu, Kaduna and Umudike Honey samples possess central analgesic activities and that the effect of both Idanre and Ewu samples is mediated possibly through the opioid receptor system.

FST is a model that is known to be sensitive to all classes of antidepressant including tricyclic antidepressants, monoamine oxidase inhibitor and selective serotonin reuptake inhibitor (Borsini and Meli, 1988 and Detke et al., 1995). There are extensive evidences to show that different types of experimental stressors induce neurochemical and hormonal changes in animal models of depression (Katz et al., 1981, Willner, 1991), however, antidepressant drugs are effective in preventing the behavioral and biochemical changes (Muira et al., 1993, 1996). Forced swimming test (FST) induced alteration in levels of monoamine and indolamines, which are reminiscent of human symptoms of depression. Depression is a collection of psychological symptoms, which include depressive thoughts, sadness, poor self-image, self-blame, guilt, low confidence and feelings of hopelessness (Jesberger and Richardson, 1985). The force swimming test is widely used screening method for antidepressants in mice (Steru et al., 1985; Cryan et al., 2002). During the tests, the mice showed alternate movements of mobility (in form of swimming, struggling and climbing) and immobility (floating or no struggling); the latter being considered to mimic a state of helplessness 
(Willner, 1984). The results obtained in the FST in mice showed that honey sample from Idanre orally administered in mice significantly decreased the duration of immobility in seconds, indicating an increase in duration of struggling in the FST. This showed that this honey sample at the doses of 10 and $20 \% \mathrm{v} / \mathrm{v}$ significantly increased the struggling time suggesting an antidepressant effect, similarly, the standard drug (Imipramine, $10 \mathrm{mg} / \mathrm{kg}$, i.p.) showed a significant ( $<0.05$ ) effect. However, other five honey samples had no significant effect on immobility time suggesting that they have no antidepressant effect in mice.

\section{Conclusion}

Most of the honey samples showed significant behavioral effects such as central inhibitory effects, anxiolytic, antinociceptive effects and only Idanre sample showed antidepressant while only Umudike sample showed significant hypnotic and partial protection of picrotoxin-induced convulsions. This study has clearly demonstrated that Nigerian honey samples can be used as nutraceutical agents. Further studies are needed to determine the toxicity potentials and various mechanism(s) of actions of these honey samples.

\section{Acknowledgements}

This research was supported by the International Foundation for Science (IFS) grant F4276-1 awarded to MA.

\section{References}

1. Abdul-Guani A.S., El-Lati S.G., Sacaan Al., Suleiman M.S., Amin R.M. (1987). Anticonvulsant effects of some Arab medicinal plants. Int J Crude Drug Res 1(25): 39-43.

2. Adebiyi F.M., Akpan I., Obiajunwa E.I., Olaniyi H. B. (2004). Chemical and physical Characterization of Nigerian Honey. Pakistan J Nutr 3(5): 278-281.

3. Ajayi A.A., Ukponmwan O.E. (1994). Evidence of Angiotensin II and Endogenous opioid Modulation of NIR in the Rat. Afr J of Med \& Med Sci 23: 287-290

4. Al-Mamary M., Al-Meeri A., and Al-Habori M. (2002). Antioxidant activities and total phenolics of different types of honey. Nutr Res 22: 1041-1047.

5. Al-Waili, N.S. (2004). Investigating the antimicrobial activity of natural honey and its effects on the pathogenic bacterial infections of surgical wounds and conjunctiva. J Med Food 7(2): 210-22.

6. Anklam E. (1998). A review of the analytical methods to determine the geographical and botanical origin of honey. Food Chem 63:549-562.

7. Bilkei-Gorzo A., Gyertyan I. (1996). Some doubts about the basic concept of hole board test. Neurobiology (Bp) 4(4): 405-15.

8. Bilsel Y., Bugra D., Yamaner S., Bulut T., Cevikbas., Turkoglu. (2002). Could honey have a place in colitis therapy? Effects of honey, prednisolone, and disulfiram on inflammation, nitric oxide, and free radical formation. Dig Surg 29: 306-312.

9. Boissier, J.R., Simon P. (1960) Planche àtrous automatisée. Thérapie 15: 1170-1174.

10. Borsini, F and Meli A. (1988). Is the forced swimming test a suitable model for revealing antidepressant activity? Psychopharmacology 94(2): 147-160.

11. Cervo L and Samani R. (1991). Effect of chronic treatment with 8-OH-DPAT in the forced swimming test requires the integrity of presynaptic serotonergic mechanism. Psychopharmacology 103: 524-528.

12. Chen R., Zhang M., Park S., Gnegy M.E. (2007). C57BL/6J mice show greater amphetamine-induced locomotor activation and dopamine efflux in the striatum than 129S2/SvHsd mice. Pharmcol Biochem Behav 87(1): 158-163.

13. Crosby, Alfred W. (2004). Ecological Imperialism: The Biological Expansion of Europe, 900-1900. Cambridge University Press,

14. Cryan J.F., Markou A, Lucki I. (2002). Assessing antidepressant activity in rodents: recent developments and future need. Trends Pharmacol Sci 23(5):238-245.

15. De Vry J, Maurel S, Schreiber R, de Beur R, Jentzsch K.R. (1999). Comparison of hypericum extracts with imipramine and fluoxetine in animals models of depression and alcoholism. Eur NeuroPsychopharmacol 9(6):461-468.

16. Detke M.J., Rickels M., Lucki L. (1995). Active behaviours in rat forced swimming test differently produced by serotonergic and noradrenergic antidepressant. Psychopharmacology 121: 66-72.

17. Dunn A.J. and Swiergiel A.R. (2005). Effects of interleukin-1 and endotoxin in the forced swim and tail suspension tests in mice. Pharmacol Biochem Behav 81 (3): 688-693.

18. Eckeli A.L., Dach F., Rodrigues ALS. (2000) Acute treatments with GMP produce antidepressant-like effects in mice. Neuroreport 11: 839-843.

19. Fessenden R. (2008). Report to the Officers and Board of Directors of the Committee for the Promotion of Honey and Health. Sacramento, CA, USA. http://www.prohoneyandhealth.com/UserFiles/Image/SymposiumReport.pdf

20. Frankel S., Robinson G.E., Berenbaum M.R. (1998). Antioxidant capacity and correlated characteristics of 14 unifloral honeys. J Apic Res 37:27-31

21. Gheldof N., Engeseth N.J. (2002). Antioxidant capacity of honeys from various floral sources based on determination of oxygen radical absorbance capacity and inhibition of in vitro lipoprotein oxidation in human serum samples. J. Agric Food Res 50:3050-5.

22. Gomes P.B., Noronha E.C., de Melo V.C.T., Bezerra J.N.S., Neto M.A., Lino C.S., Vasconcelos S.M.M., Viana G.S.B. de Sousa F.C.F. (2008). Central effects of isolated fractions from the root of Petiveria alliacea L. (tipi) in mice. J Ethnopharmacol 120: 209-214.

23. Gross H., Polagruto J., Zhu Q., Kim S., Schramm D., Keen C. (2004). Effect of honey consumption on plasma antioxidant status in human subjects. Paper presented at the 227th American Chemical Society Meeting, Anahein CA.

24. Heo H., Park Y., Suh Y., Choi S et al. (2003). Effects of oleamide on choline acetyltransferase and cognitive activities. Biosci 
Biotechnol Biochem 67:1284-1291.

25. Janssen PA, Niemegeers CJ, Dony JG. (1963).The inhibitory effect of fentanyl and other morphine-like analgesics on the warm water induced tail withdraw reflex in rats. Arzneimittelforschung 13: 502-7.

26. Jesberger J.A and Richardson J.S (1985). Animal models of depression: Parallels and correlates to severe depression in humans. Biol Psychiatry 20:764-784.

27. Juszczak Leslaw, Robert Socha, Jacek Roznowski, Teresa Fortuna, Karolina Nalepka (2009) Physicochemical properties and quality parameters of herbhoneys. Food Chem 113: 538-542.

28. Katz R.J., Roth K.A., and Carrol B.J. (1981). Acute and chronic stress effects on open field activity in the rat: implications for a model of depression. Neurosci Biobehav Rev 5:247-251.

29. Lister R.G. (1987a). The use of a plus-Maze to measure Anxiety in the mouse. Psychopharmacology 111:323-333.

30. Lister R.G. (1987b). Reversal of the intrinsic effects of Ro15-4513 on exploratory behavior by two benzodiazepine receptor antagonists. Neurosci Lett 79:306-10.

31. Mamiya T., Asanuma T., Kise M., Ito Y., Mizukuchi A., Aoto H., Ukai M. (2004). Effects of Pre-germinated Brown Rice on $\beta$ Amyloid Protein-induced learning and memory deficits in mice. Biol Pharm Bull 27 (7):1041-1045.

32. Muira H., Naoi M., Nakahara D., Nagatsu T. (1993). Changes in monoamine levels in mouse brain elicited by forced swimming stress and protective effect of a new monoamine oxidase inhibitor, RS 8359. J Neural Transmission (Gensect) 94:175-187.

33. Muira H., Naoi M., Nakahara D., Ohta T., and Nagatsu T. (1996). Effects of moclobemide on forced swimming stress and brain monoamine levels in mice. Pharmacol Biochem Behav 53 (2) :469-475.

34. Molan PC. (1996). Authethenticity of honey: In: Ashurst PR, Dennis MJ, editors. Food Authentication. London: Blackie Academic and Professional. p.259-303.

35. Parle M and Dhingra D. (2003). Ascorbic Acid: A promising memory-enhancer in mice. J Pharmcol Sci 93: 129-135.

36. Paul I.M., Beiler J., McMonagle A., Shaffer M. (2007). Effect of honey, dextromethorphan, and no treatment on nocturnal cough and sleep quality for coughing children and their parents. Arch Pediatr Adolesc Med 161(12):1140-6.

37. Pellow S., Chopin P., File S.E., Briley M. (1985). Validation of open:closed arm entries in an EPM as ameasure of anxiety in the rat. J Neurosci Methods 14 (3), 149-167.

38. Perazzo F.F., Carvalho J.C., Carvalho J.E., Rehder V.L. (2003). Central properties of the essential oil and the crude ethanol extract from aerial parts of Artemisia annua L. Pharmacol Res 48(5): 497-502.

39. Pine D.S., Wasserman, G.A., Workman S.B. (1999). Memory and anxiety in perpubertal boys at risk for delinquency. J Am Acad Child Adolesc Psychiatry 38:1024-1031.

40. Porsolt R.D., Anton G., Blavet N and Jafre M. (1978). Behavioural despair in rats:a new model sensitive to antidepressant treatments. Eur J Pharmacol 47:379-391.

41. Porsolt R.D., Bertin, A., Jalfre, M. (1977a). Behavioral despair in mice: a primary screening test for antidepressants. Arch Int Pharmacodyn Ther 229:327-36.

42. Porsolt R.D., Le Pichon, M., Jalfre, M. (1977b). Depression: a new animal model sensitive to antidepressant treatments. Nature 266(5604): 730-2.

43. Rodgers RJ and Cole J.C, (1994). The elevated plus maze: Pharmacology, Methodology and Ethology, in Ethology and psychopharmacology (Cooper S.J and Handrie C.A eds) John Willey \& Sons, Baltimore. pp. 45-60.

44. Romero E.M., Fernández B., Sagredo O., Gomez N., Urigüen L., Guaza C., De Miguel R., Ramos J.A., Viveros M.P. (2002). Antinociceptive, behavioural and neuroendocrine effects of CP 55,940 in young rats. Brain Res Dev Brain Res 136(2): 85-92.

45. Rujjanawate C., Kanjanapothi D., Panthong A. (2003) Pharmacological effect and toxicity of alkaloids from Gelsemium elegans Benth. J Ethnopharmacol 89: 91-95.

46. Sadock B.J., Sadock V.A. (2003). Kaplan and Sadock's synopsis of psychiatry-Behavioral Sciences/Clinical psychiatry, $\left(9^{\text {th }}\right.$ ed.). Lippincott Williams and Wilkins, Philadelphia. (Chapter 16).

47. Sarter M., Bodewitz G, Stephens, DN. (1988). Attenuation of scopolamine-induced impairment of spontaneous alternation behaviour by antagonist but not inverse agonist and beta-carbolines. Psychopharmacology 94:491-495.

48. Steru L., Chermat, R., Thierry, B., Simon, P. (1985). The tail suspension test: a new method of screening antidepressants in mice. Psychopharmacology (Berl). 85:367-70.

49. Taormina PJ, Niemira BA, Beuchat LR. (2001). Inhibitory activity of honey against food borne pathogens as influenced by the presence of hydrogen peroxide and level of antioxidant power. Int J Food Microbiol 69(3):217-25.

50. Trullas R, Skolnick P. (1993). Differences in fear motivated behaviors among inbred mouse strains. Psychopharmacology (Berl) 111(3): 323-31.

51. Waldegrave W. (1986). Council Directive 86/609/EEC of 24 November 1986 on the approximation of laws, regulations and administrative provisions of the member states regarding the protection of animals used for eexperimental and other scientific purposes. Pg1-46.

52. White J.W. (1979). Composition of honey. In E. Crane (Ed.), Honey: A comprehensive survey London: Heinemann. (pp. 157-158).

53. Willner, P. (1984). The validity of animal models for depression. Psychopharmacology 83:1-16.

54. Willner, P. (1991). Animal models as simulations of depression. Trends in Neuroscience 121:131-136. 